OPEN ACCESS

Edited by:

Stacy Michelle Philpott, University of California, Santa Cruz, United States

Reviewed by:

Jim Sprinkle,

University of Idaho, United States Wayne Coblentz, Agricultural Research Service,

United States Department of Agriculture (USDA), United States

*Correspondence: Matthew R. Beck Matt.Beck@lincolnuni.ac.nz Pablo Gregorini

Pablo.Gregorini@lincoln.ac.nz

Specialty section:

This article was submitted to Agroecology and Ecosystem Services, a section of the journal Frontiers in Sustainable Food Systems

Received: 29 March 2020 Accepted: 06 April 2021 Published: 28 April 2021

Citation:

Beck MR and Gregorini P (2021) Animal Design Through Functional Dietary Diversity for Future Productive Landscapes. Front. Sustain. Food Syst. 5:546581. doi: 10.3389/fsufs. 2021.546581

\section{Animal Design Through Functional Dietary Diversity for Future Productive Landscapes}

\author{
Matthew R. Beck* and Pablo Gregorini* \\ Faculty of Agriculture and Life Sciences, Lincoln University, Christchurch, New Zealand
}

Pastoral livestock production systems are facing considerable societal pressure to reduce environmental impact, enhance animal welfare, and promote product integrity, while maintaining or increasing system profitability. Design theory is the conscious tailoring of a system for a specific or set of purposes. Then, animals-as biological systems nested in grazing environments - can be designed in order to achieve multi-faceted goals. We argue that phytochemical rich diets through dietary taxonomical diversity can be used as a design tool for both current animal product integrity and to develop future multipurpose animals. Through conscious choice, animals offered a diverse array of plants tailor a diet, which better meets their individual requirements for nutrients, pharmaceuticals, and prophylactics. Phytochemical rich diets with diverse arrangements of plant secondary compounds also reduce environmental impacts of grazing animals by manipulating the use of $\mathrm{C}$ and $\mathrm{N}$, thereby reducing methane production and excretion of $\mathrm{N}$. Subsequently functional dietary diversity (FDD), as opposed to dietary monotony, offers better nourishment, health benefits and hedonic value (positive reward increasing "liking" of feed), as well as the opportunity for individualism; and thereby eudaimonic well-being. Moreover, phytochemical rich diets with diverse arrangements of plant secondary compounds may translate in animal products with similar richness, enhancing consumer human health and well-being. Functional dietary diversity also allows us to design future animals. Dietary exposure begins in utero, continues through mothers' milk, and carries on in early-life experiences, influencing dietary preferences later in life. More specifically, in utero exposure to specific flavors cause epigenetic changes that alter morphological and physiological mechanisms that influence future "wanting," "liking" and learning of particular foods and foodscapes. In this context, we argue that in utero and early life exposure to designed flavors of future multifunctional foodscapes allow us to graze future ruminants with enhanced multiple ecosystem services. Collectively, the strategic use of FDD allows us to "create" animals and their products for immediate and future food, health, and wealth. Finally, implementing design theory provides a link between our thoughtscape (i.e., the use of FDD as design) to future landscapes, which provides a beneficial foodscape to the animals, an subsequently to us.

Keywords: functional dietary diversity, grazing ruminant production, welfare, environmental impact, product quality, animal design 


\section{INTRODUCTION}

Pastoral livestock producers are facing multi-faceted issues. Consumers are demanding "cleaner and greener" production systems with "happier" animals producing "healthier products" for humans. Specifically, ruminants have been identified as a significant source of greenhouse gas (GHG) emissions and the removal of red meat from diets has been suggested as a mitigation of anthropogenic GHG option (Harwatt et al., 2017; Springmann et al., 2018). Consumers also have become increasingly more willing to buy animal products associated with husbandry practices that enhance animal well-being and welfare (Napolitano et al., 2010). Further, reductions in red meat and dairy products in human diets have been suggested to reduce negative postprandial health and collateral effects (Becerra-Tomás et al., 2016; Boada et al., 2016). Accordingly, a survey of 329 vegans, determined that 90,69 , and $47 \%$ of these people opted for a vegan diet due to concerns on animal welfare, personal health, and environmental impacts, respectively, with $82 \%$ mentioning more than one concern (Janssen et al., 2016). These concerns are multifaceted and ultimately relate to product integrity. As such, producers are pressured to respond to consumers' concerns while maintaining or increasing animal performance to remain economically viable.

Design theory is used in other fields, such as architecture, management, and finance, to address multifaceted issues (Baskerville and Pries-Heje, 2010). Design theory is defined as the pre-planned implementation framework of knowledge to generate methods and means and thereby product/s, which addresses pre-outlined single or multifaceted problems. As design theory and practice is rooted in known knowledge, it arises from pre-explored and established theories, i.e., kernel theories (Walls et al., 1992). In this context, we point out that functional phytochemical rich diets with diverse arrangements of plant secondary compounds (PSC) as a result of either taxonomical diversity or PSC rich chemical composition is a key tool to design animals that produce products with integrity. Obviously, taxonomic diversity increases phytochemical richness; however, just because a set of plant species can have complementary plant primary compounds (PPC) does not mean that they have complementary PSC. Also, different species of plants might have similar (e.g., similar types of tannins) or synergistic types of PSC (e.g., alkaloids and condensed tannins, see Provenza et al., 2007; Lyman et al., 2011; Catanese et al., 2014; Gregorini et al., 2017; Villalba et al., 2019). Both PSC diversity and PPC, adds another dimension which must be functional. Therefore, while likely overlapping, herein we separate benefits of taxonomic and PSC dietary diversity. Additionally, one key objective of this manuscript is to provide evidence of how dietary diversity can improve ruminant production; however, how this diversity is implemented in order to be functional is context specific (e.g., climatic conditions, ruminant production system, physiological state of the livestock, etc.). As such, from here on we will refer to functional dietary diversity (FDD). It is impossible to discuss what FDD looks like in every production system, which is where part of the functionality described here comes into play. For something to be functional it must be context specific; however, by implementing concepts described in this work we feel that multi-objective goals can be addressed in many production settings.

Design theory has yet to be applied to livestock and their products; thus, and due to the multifaceted societal pressure of pastoral production systems, we argue that design theory can provide a framework to alleviate such a pressure while maintaining farms and agroecosystems profitability. After first introducing the design concept and describing the Kernel Theories behind FDD as a tool for designing animals, we contend that FDD can be used for animal design. Moreover, we outline how FDD can answer each and all of the challenges mentioned above at the same time for the benefit of today and future pastoral livestock production systems.

\section{DESIGN THEORY IN THE CONTEXT OF FUNCTIONAL DIETARY DIVERSITY}

We borrow the definition of design theory from the information systems field, as the pre-determined implementation of what is known to produce something (a process or product) which addresses pre-outlined multi-faceted problems (Walls et al., 1992; Gregor and Jones, 2007). Design theory can be split into two aspects, process and product design (Walls et al., 1992). Herein we discuss design theory for a product (i.e., animal and its product). Walls et al. (1992) describe design theory for products through a series of components with the first termed the meta-requirements, which are the designer's goals. The second component is the meta-design, defined as hypothetic artifacts to meet the meta-requirements. The meta of these two components relates to the fact that the theory does not address a single problem (i.e., requirement) or create a single artifact (i.e., design), but a cluster of problems and artifacts (Walls et al., 1992). The third component of design theory are the kernel theories (i.e., theories derived from experimentation) behind the metadesign and which can achieve the meta-requirements. The final component is testable product hypothesis (Walls et al., 1992), representing that the meta-design produces a product, which meets the meta-requirements. Although design theory is used in many fields, it has not been applied to grazing ruminants. In such a context, design theory can be reworded as the implementation of established theories to grazing ruminants in order to obtain animal products which achieve pre-outlined meta-requirements.

Figure 1 depicts how the components of design theory help framework dietary diversity as a tool to design ruminant livestock. Our meta-requirements are goals, which current and future pastoral enterprises are pressured to achieve: (1) enhance animal welfare, (2) increase animal performance, (3) reduce environmental impact, (4) improve product integrity, and (5) rapidly adapt animals to evolving foodscape designs for ecosystem services. Providing FDD to ruminants is the meta-design, and the testable-design product hypothesis is that products from pastoral systems, implementing FDD will fulfill the meta-requirements. The following sections outlines specific kernel theories and explains how FDD (i.e., the meta-design) 


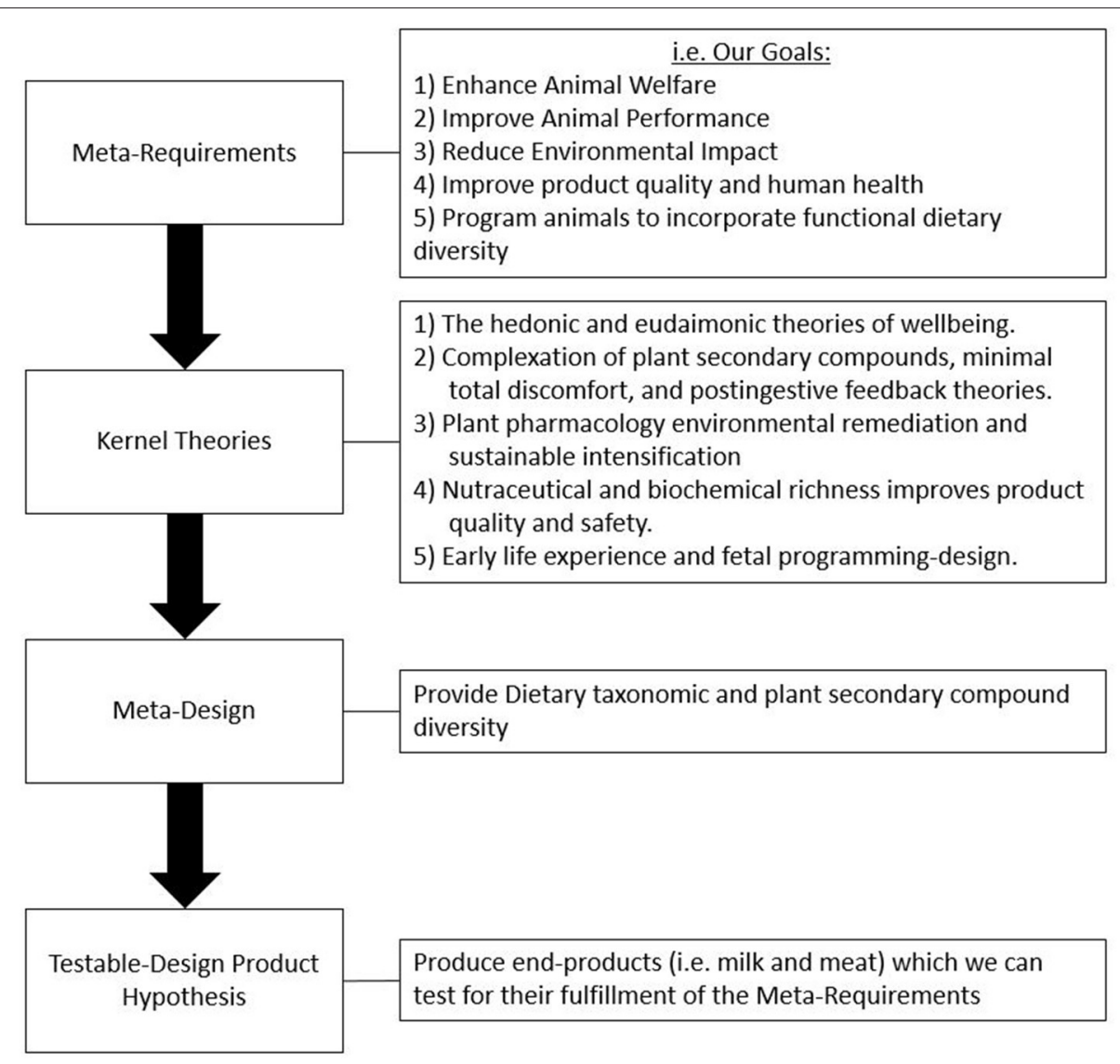

FIGURE 1 | The process of design theory for products and how this process can be applied to animal design through dietary diversity (Adapted from Walls et al., 1992).

can be used for animal design to achieve our meta-requirements, shown in Figure 2.

\section{Enhancing Animal Well-Being and Welfare}

Animal well-being and welfare are often wrongly used interchangeably (Barber, 2009). Animal well-being refers to the mental state, for example subjective interpretation of different clusters of experiences, i.e., emotions (Barber, 2009; Boissy and Erhard, 2014; Gregorini et al., 2017). Welfare instead refers to the animal state as a whole, including well-being and health, as well as iterative experiences with the feeding environments (Barber, 2009; Panzera, 2013). The following sections explore how animal well-being and welfare can be enhanced by design of diverse functional foodscapes.

\section{Taxonomic Diversity}

Eudaimonic well-being was proposed by Aristotle and lately discussed in diverse scientific contexts (Deci and Ryan, 2008; Nordenfelt, 2011; Harfeld, 2013; Beck and Gregorini, 2020). In our meta-design context, eudaimonic well-being may best apply to grazing ruminants based on function. Beck and Gregorini (2020) suggested that eudaimonic well-being is achieved through the pursuit of their telos; as telos has been defined as one's purpose. Therefore, when an animal is allowed to achieve/pursue their telos, eudaimonic well-being is enhanced, which can only occur through individual choices (Harfeld, 2013; Beck and Gregorini, 2020). This theory closely relates to the "A Life Worth Living" (Mellor, 2016) or "the Good Life" (Harfeld, 2013) concepts of animal welfare, which emphasize positive welfare as opposed to merely the absence of negative welfare (e.g., pain and fear). As such, experiments oriented around these theories require markers of positive welfare. Some suggested markers of positive welfare include: behavioral markers (i.e., facial expression, vocalizations, and how animals interact with their surroundings), cognitive processes, and physiological markers, but more work is required to further develop these markers (Yeates and Main, 2008). Beck and Gregorini (2020) reported FDD and choice may improve eudaimonic well-being by allowing the animals to display individuality, i.e., pursue their telos. Telos in grazing ruminants may be achieved individually or collectively, evidenced by individual animal and herd personalities as first suggested by (Gregorini et al., 2017) and later modeled by Moreno García et al. (2020) (for further detail on this concepts, the reader is directed to Moreno García et al., 2020). Genetically related personalities and grazing personalities are interesting and may 


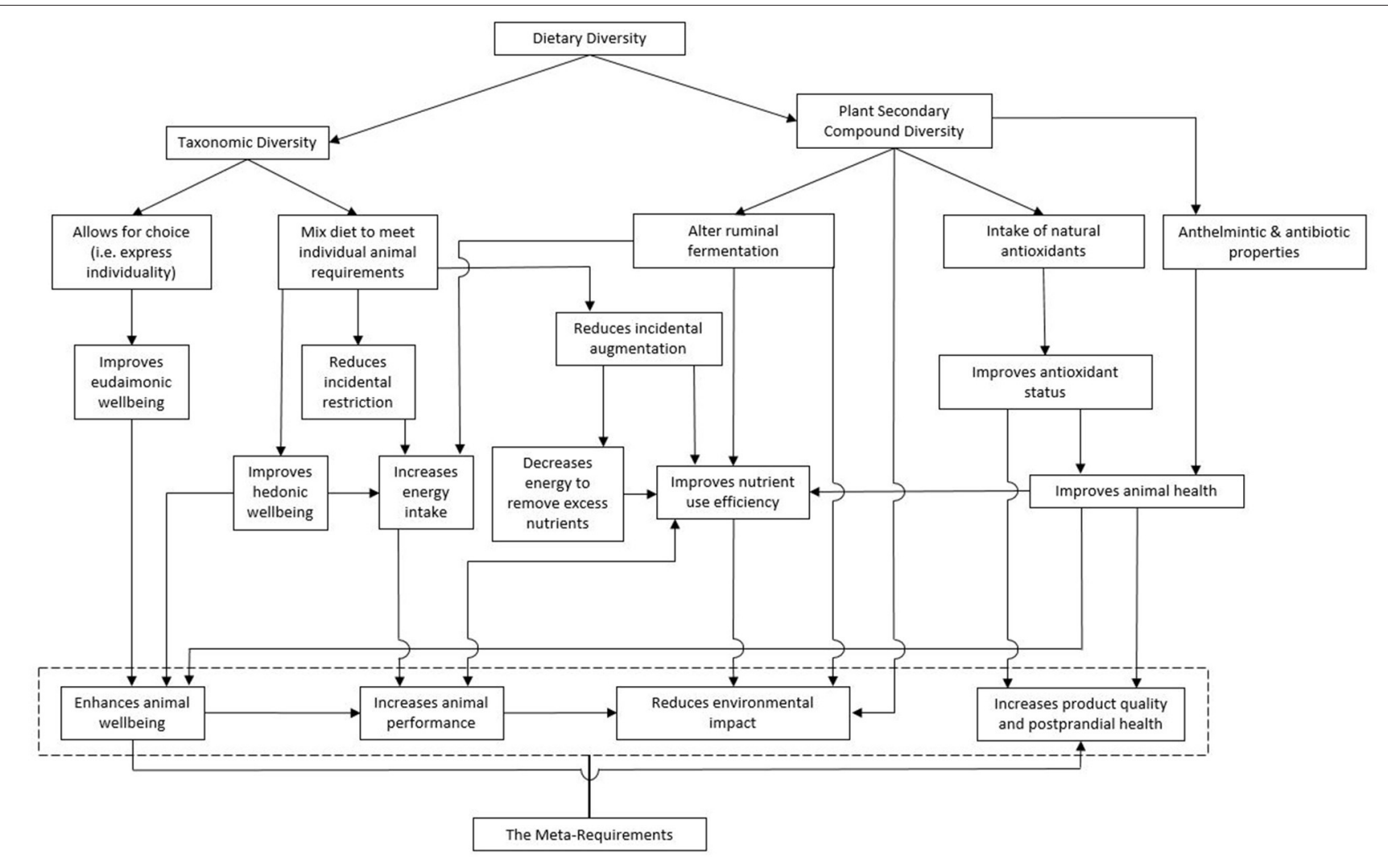

FIGURE 2 | The "Kernel Theories" behind how FDD (i.e., the meta-design) can be implemented to meet our meta-requirements.

provide evidence of telos in grazing animals, as it has been said that telos is intrinsic in the genetic coding of animals (Harfeld, 2013). Additionally, evidence for eudaimonic wellbeing in non-human animals is available. For example, giant pandas had lower urinary cortisol concentration when they were allowed to choose between enriched and non-enriched environments (Owen et al., 2005). Improved eudaimonic wellbeing through dietary choice may have been measured in several experiments. When lambs were allowed to choose between dietary constituents, compared to a total mixed ration; they had lower blood cortisol and lower neutrophil-to-lymphocyte ratio, indicating less physiological stress (Catanese et al., 2013). Villalba et al. (2012) also reported that lambs provided choice between dietary components compared to a mix of all the dietary components experienced less physiological stress. Individuality, and thereby telos, is related to specific genes (Boissy and Erhard, 2014). Thus, when allowed to express their individual choice and therefor pursue their telos, we hypothesis that eudaimonic well-being is enhanced.

Another means for FDD to enhance animal well-being is through improved hedonic well-being, which relates to pleasure, and has been suggested to be the balance between negative and positive affective states and emotions (Deci and Ryan, 2008; Beck and Gregorini, 2020). Affective states are internal conditions, including subjective interpretations of internal states (Gygax,
2017) influenced by a variety of systems stimuli (Gregorini et al., 2015, 2017). Physiologically, hedonic well-being is related to the dopamine, GABA, opioid, and cannabinoid systems, which are associated with eating disorders and addictions (Berridge and Kringelbach, 2008; Berridge, 2009) and meal phases and foraging behavior by ruminants (Ginane et al., 2015). As such, like in humans, there is a strong relationship between food and hedonic pleasure.

While providing pleasure, these systems are also behind meal behavior and phases: "wanting," through dopamine, and "liking," GABA, opioid, and cannabinoid, for specific foods and subsequently altering voluntary intake (Ginane et al., 2015). By mixing diets through choice, individual requirements for nutrients (under the right circumstances), medicines and prophylactics are better met, reducing incidental restriction and augmentation (Villalba et al., 2015; Gregorini et al., 2017). This is supported by feed conversion efficiency increments with the availability to choose dietary components freely (Nocek et al., 1986; Atwood et al., 2001, 2006; Yurtseven and Görgülü, 2004). Thus, increasing their ability to meet individual specific requirements, would result in a more positive internal state and would increase the hedonic value of their diets, thereby improving animal well-being and welfare. Ultimately, dietary choice may allow grazing managers and the animals to design "positive-emotional" foodscapes. 


\section{Phytochemical Rich Diets and Plant Secondary Compound Diversity}

Phytochemical rich diets through PSC diversity improves animal well-being and welfare differently than mere taxonomic diversity. Plant secondary compounds (especially phenolic compounds) are often natural antioxidants that reduce oxidative stress (Lee et al., 2017; Beck and Gregorini, 2020). Oxidative stress occurs when oxidant production outpaces the ability of antioxidant defense, which occurs following a stressor (Celi and Gabai, 2015). High concentration of circulating oxidants damage molecules, such as lipids and DNA, eliciting metabolic disorders, especially in high yielding animals transitioning to lactation (e.g., mastitis, metritis, hypocalcaemia, and retained placenta; Lykkesfeldt and Svendsen, 2007). Oxidative stress has been linked to several diseases common to other classes of livestock too, i.e., bovine respiratory disease in growing cattle (Chirase et al., 2004). As oxidative stress states can be predicted, phytochemical rich and functional diets through PSC arrangements can be ex-anti designed to alleviate oxidant loads.

Animal health relates to well-being and welfare. As such, freedom from disease has been listed as one of the "five freedoms" commonly used as the basis for the ethical management of animals (Webster, 1994, 2016). Additionally, there is a direct link between oxidative damage and physiological stress. For example, isoprostanes are prostaglandin analogs which are products of oxidative damage to arachidonic acid (Montuschi et al., 2007). Prostaglandins are involved in chemical and physical injury by increasing inflammation (Chand and Eyre, 1977). As isoprostanes are able to bind to similar receptors as prostaglandins, they cause inflammation and as such are pathophysiological mediators of inflammation from oxidative damage (Montuschi et al., 2007). Recently, isoprostanes have been suggested as the most reliable markers of oxidative damage to lipid (Celi, 2011) and related with physiological stress. The isoprostane, 8 epi-prostaglandin F-2 $\alpha$ is positively correlated with serum cortisol concentrations (Kasimanickam et al., 2018, 2019), providing a direct relationship between oxidative damage, increased discomfort and then reduced wellbeing. Uncomfortable experiences lead to negative emotions, reducing pleasure and subjective well-being. Thus, by providing antioxidant support with FDD based on arrangements of PSC, we can improve well-being.

Additionally, PSC exhibit anthelmintic properties with animals adjusting their partial preference to consume them under gastrointestinal parasitic loads (i.e., self-medicate). Parasitized sheep preferred condensed tannins [e.g., quebracho (Schinopsis quebracho-colorado) tannins] with subsequent reductions in parasitic burdens compared to non-infected sheep (Lisonbee et al., 2009). Reductions in pathogenic bacteria also occurs through the antibiotic activity of some PSC. Ultee et al. (2002) proposed the antimicrobial mode of action of some PSC, e.g., carvacrol, to be similar to synthetic antibiotics such as ionophores (e.g., monensin by transporting $\mathrm{H}^{+}$across the bacterial membrane and removing $\mathrm{K}^{+}$back across the bacterial membrane; Bergen and Bates, 1984). Another example of antimicrobial activity can be seen in saponins ability to kill protozoa by forming complexes with sterols in the membrane surface (Wina et al., 2005). Reductions in protozoa can improve microbial protein synthesis, slow down ruminal nitrogen cycling and reduce urinary nitrogen excretion, as well as decrease $\mathrm{CH}_{4}$ emissions (Wina et al., 2005). Lu and Jorgensen (1987) reported reductions in protozoal counts by 34 and $66 \%$ for 2 and $4 \%$ lucerne saponins additions, respectively, when added to the diet of mature wethers. In a separate experiment, saponins extracted from lucerne roots resulted in linear reductions in ruminal protozoa numbers (Klita et al., 1996). Phenolic compounds also exhibit antimicrobial effects. For example, the isoflavonoid, biochanin A, from red clover (Trifolium pretense) has been shown to inhibit Clostridium sticklandii, which is a strain of bacteria known to be largely responsible for amino acid deamination in the rumen (Flythe and Kagan, 2010). Additionally, common phenolic acids have been shown to greatly increase Escherichia coli O157:H7 death rates, increasing product safety (Wells et al., 2005). Many families of PSC show antimicrobial properties and target a range of microorganisms, resulting in many subsequent effects including greater rumen fermentation and microbial metabolizable protein yield and health benefits. Collectively, these benefits will improve the internal state (e.g., nutrient supply and comfort) and sense of well-being, thereby welfare.

Finally, phytochemical rich diets through PSC alter animal response to stress. For example, following an adrenocorticotropic hormone challenge, sheep given either no polyphenols or one of four polyphenolic products exhibited variable results, but overall the polyphenol had beneficial responses to immune function (Sgorlon et al., 2012). This indicates that designed PSC arrangements can improve livestock immune response to physiologically stressful events. Collectively, PSC reduce oxidative stress, parasitic and pathogenic bacteria load, and improve the immune response of stressed animals, improving their well-being and welfare.

\section{Food for Thought}

Improving animal well-being and welfare was the first proposed meta-requirement (Figure 1) in response to societal demands for animal well-being and welfare and because of the ethical "use" of ruminants for food production. Additionally, many of the other meta-requirements are unachievable if animal wellbeing and welfare are not first addressed. As illustrated in Figure 2, taxonomic diversity may enhance eudaimonic wellbeing by allowing choice, leading to the display of individuality. Plant secondary compounds can improve health through antioxidant defense, providing anthelmintic properties, killing pathogenic bacteria and improving immune response following physiologically stressful events. Therefore, it is hypothesized that FDD can improve hedonic well-being by animals being able to select their own nutrition, flavors, and medicines leading to enhanced pleasure and positive emotions. By these means, FDD achieves the first meta-requirement.

\section{Increasing Animal Production Taxonomic Diversity}

Taxonomic diversity enhances biochemical diversity providing a range of plant primary (e.g., protein, carbohydrates, and minerals) and secondary compounds. By having more choice 
between plant species containing different levels of plant primary and secondary compounds, ruminants tailor diets in order to meet specific individual dietary and medicine requirements (Villalba et al., 2015) and avoiding incidental restriction and augmentation (Gregorini et al., 2017). Incidental restriction is the inability to meet requirements for nutrients which are in lower concentrations in the diet and incidental augmentation is the over ingestion of particular nutrients in order to meet the requirements for nutrients that are in lower concentrations (Villalba et al., 2015). Incidental restriction reduces performance as the animal fails to meet nutrient requirements. For example, in ruminants grazing dormant pastures, the protein content of forages is often below the requirements for microbial function (McCollum and Horn, 1990). As bacteria require carbon and nitrogen $(\mathrm{N})$ sources, forage fermentation is reduced, as is nutrient supply from the rumen, which subsequently impairs animal performance. Incidental augmentation may likewise reduce animal performance as the removal and excretion of excess nutrients cost energy. For example, over-ingestion of $\mathrm{N}$ is common among ruminants in high-producing temperate pastoral systems. This excess protein is converted to urea (i.e., ureagenesis), and then either recycled back to the rumen or excreted in through urine or in milk of lactating animals (Lobley and Milano, 1997). Ureagenesis represents an energy loss and in sheep has been related to $4 \%$ of metabolizable energy intake (Waghorn and Barry, 1987). Therefore, over ingestion of nutrients reduces nutrient use efficiency and may subsequently hinder animal performance.

Another means that taxonomic diversity can increase performance is by enhancing feedstuff's hedonic value (i.e., postprandial pleasure). Hedonic well-being (i.e., pleasure) modulates eating behavior and rate of intake. The hedonic value of feed alters the "liking" of feed components through the opioid and cannabinoid systems (Ginane et al., 2015). Dietary diversity increases hedonic feed value through several ways. The first is through the ingestion of different flavors, providing stimulation that motivates animals to increase intake. Villalba et al. (2011) offered one group of lambs a choice between lucerne and barley diets (75:25) either unflavored or flavored with sweet, umami, or bitter flavors compared to lambs who were offered the same diet but only one flavor profile. It was found that the lambs provided a range of flavors had greater and less variable day-to-day intake and tended to have greater performance compared with the lambs which had no choice. This would imply that providing a diverse diet with a range of flavors will increase energy intake by providing oral-sensorial stimulation.

The other means by which dietary choice enhances pleasure is by animals "formulating" their own individual diet through "nutritional wisdom" (Provenza et al., 2003; Provenza, 2018). Several works refute the ability of ruminants to select for diets based on their internal status or their nutritional requirements. One argument against "nutritional wisdom" is the lack of efficacy of cafeteria style mineral feeders, which is where one allows animals to select minerals in separate compartments free choice. For example, Muller et al. (1977) fed lactating dairy cows either alfalfa hay or corn silage as the forage source and the cows were then allowed to choose from a cafeteria style mineral feeder. The cows consuming alfalfa hay still consumed calcium from the mineral feeder, even though the basal diet provided adequate calcium to meet their estimated requirements, thereby consuming an estimated $163.5 \mathrm{~g}$ of calcium/d over their estimated requirements. Using this as an example, Schingoethe (2017) claimed that, "A cow's wisdom to select what it needs in order to consume a nutritionally balanced diet is not great." However, the cows fed alfalfa hay also consumed $231.7 \mathrm{~g}$ of potassium/d over their estimated requirements at the same time consumed much less potassium through the mineral feeder compared with the corn silage fed cows, with $99.9 \%$ of potassium intake arising from their ration (Muller et al., 1977). Potassium and magnesium have an antagonistic relationship and magnesium has been reported to be important in the homeostatic pathway for regulating blood calcium concentrations (van Mosel et al., 1990), so that the additional consumption of calcium above their requirements may be the animal's attempt at correcting a calcium imbalance. Further, when this is coupled with the corn silage fed cows adequately self-selecting mineral intake through the cafeteria style feeder and achieving near their estimated requirements, we believe that this manuscript (Muller et al., 1977), which Schingoethe (2017) used to support their claim that animal's do not possess adequate "nutritional wisdom," can actually provide support that cattle can select diets to meet their requirements.

Another argument against nutritional wisdom in ruminants used by Schingoethe (2017) is works which have shown that when animals are allowed free choice between the forage and concentrate the cows consumed in excess of their requirements and milk production was not increased compared with TMR fed cows (based on a 1927 experiment, which we could not obtain, but was cited by Spahr, 1977). However, several experiment have shown improvements in feed efficiency by allowing animals free choice between the forage and concentrate portions of the rations (Nocek et al., 1986; Atwood et al., 2001, 2006; Yurtseven and Görgülü, 2004). Further support for ruminants' nutritional wisdom is found in experiments which explore the sorting behavior of TMR fed cattle. As reviewed by Miller-Cushon and DeVries (2017), both calves and cows alter their sorting behavior based on energy demands, availability of supplements, changing metabolic status, and ruminal $\mathrm{pH}$. Ultimately, the debate around if ruminants possess nutritional wisdom continues. We believe that ruminants do have the ability to select diets which can meet their nutritional requirements; however, these animals are not without fault and their decisions may not always be perfect. For example, even experienced animals can over-ingest plants high in toxins and experience poisoning. This phenomenon may be a result of a nutrient imbalance, which has been shown to reduce dietary neophobia in an attempt to find a food source which corrects their imbalance (Provenza, 1995). As ruminants are not infallible, there is still a need for grazing management; however, if producers acknowledge the animals' nutritional wisdom, they may be able to manage the livestock nutritionally.

If animals do possess nutritional wisdom, meeting one's requirements would lead to a better internal state, increasing positive emotions and pleasure (i.e., enhance hedonic wellbeing; Beck and Gregorini, 2020). Additionally, monotonous diets lead to incidental augmentation and thereby over ingestion 
of primary nutrients (e.g., protein); causing discomfort (i.e., reduced well-being; Provenza, 1995). Fermentation products which are associated with carbohydrates (e.g., the volatile fatty acid, propionate) has been shown to cause malaise (Provenza, 1995). Ralphs et al. (1995) reported that low-levels of propionate supplementation to their diet $(0.381 \mathrm{Mcal}$ of gross energy supplied) caused satiety, while high-levels of propionate addition (0.762 Mcal of gross energy supplied) caused food aversion. Villalba and Provenza (1997) reported that lambs fed increasing levels of sodium propionate $(4,8$, or $12 \%$ of daily digestible energy) associated with different flavors had a preference for flavors that they were conditioned to relate to the lower additions of sodium propionate, but had significant aversions to the flavors associated with the higher levels of sodium propionate. Further, as ruminants increase ingestions of ruminal degradable protein, excessive amounts of ruminal ammonia are produced, absorbed into the blood stream, and then converted to urea, which causes discomfort and malaise (Provenza, 1996). Over ingestion of specific primary nutrients can cause malaise and subsequent aversions, reducing food intake. Even though these examples of nutrient imbalances were created artificially, they still provide support for how incidental augmentation can cause discomfort and thereby reduce the hedonic feed value of specific feeds, which would result in reduced animal performance.

By improving animal well-being (both hedonic and eudaimonic) and welfare, animal performance improves. Poor welfare conditions with high stocking density have been shown to increase somatic cell count and reduce milk yield in dairy ewes (Caroprese et al., 2009). Likewise, following isolation, lactating ewes with lower cortisol levels had 19\% greater milk yield than lactating ewes with high cortisol levels (Caroprese et al., 2010). This relationship between physiological stress has been reported in growing livestock too. Lambs had lower plasma cortisol concentration when they were allowed to choose between 4 dietary components compared to lambs who were provided all of the dietary components in a total mixed ration (Villalba et al., 2012). These results were later confirmed in a similar experiment by Catanese et al. (2013), who determined that allowing lambs to choose between foods contrasting in protein:energy ratios reduced plasma cortisol concentration compared to lambs who were provided all of the foods in a total mixed ration.

Due to the relationship between welfare and performance, animal productivity and longevity has been suggested as an indicator of welfare (Barrell, 2019). Since welfare is related to performance there is economic incentive to design dietary management, which allows animals to choose and display individuality and thereby improving eudaimonic well-being. Also meeting individual requirements may increase positive emotions that enhance hedonic well-being, can improve animal welfare and subsequently performance. This is supported by both the experiments of Villalba et al. (2012) and Catanese et al. (2013) who reported that lambs offered diverse diets had lower blood cortisol and several studies which have provided dietary choice to ruminants and determined performance benefits (Nocek et al., 1986; Atwood et al., 2001, 2006; Yurtseven and Görgülü, 2004). Additionally, Villalba et al. (2012) found a tendency for greater rates of gain by the lambs offered choice compared with those provided the monotonous diet. None of the supporting examples provided have directly illustrated that dietary choice reduced physiological stress and subsequent increased animal performance. However, experiments have reported that dietary choice has reduced physiological stress and increased performances separately. Subsequent research is thus required to definitively demonstrate that dietary choice reduces physiological stress and improves performance.

\section{Phytochemical Rich Diets and Plant Secondary Compound Diversity}

Ingestion of PSC alters rumen function in terms of fermentation and site and extent of digestion. Bioflavex (Interquim SA, Barcelona, Spain), a flavonoid based product, increased $\mathrm{pH}$ in vitro (Seradj et al., 2014) and in vivo in ruminants (Balcells et al., 2012; Seradj et al., 2016) challenged with highly fermentable diets. The amelioration of acidosis was due to reductions in ruminal lactate, resulting from incremental increases in Megaesphaera elsdenii population, which is a lactate utilizing rumen bacteria (Seradj et al., 2016). Reviews by Waghorn and McNabb (2003) and Waghorn (2008) discussed the impact of tannins on ruminant digestion. Tannins bind proteins, reducing ruminal protein digestion, decreasing ammonia production, and in turn increasing true protein flow to the small intestine. Tannins also reduce digestibility and fermentation rates, as well as shift fermentation patterns toward glucogenic volatile fatty acids, which reduces methane production (Waghorn and McNabb, 2003; Waghorn, 2008). Glucogenic fermentation products also increase nutrient use efficiency independently of dry matter intake, resulting in greater animal performance.

Legumes containing condensed tannins increase animal performance compared to grass based diets and other legumes like lucerne (Medicago sativa) and white clover (Trifolium repens; Waghorn, 2008). Wang et al. (1996) reported that as compared with lucerne, Lotus corniculatus (34 g condensed tannins $/ \mathrm{kg}$ DM) fed to lambs without polyethylene glycol (PEG; binds extractable condensed tannins) had $8.8 \%$ greater average daily gain with $9.8 \%$ less DMI, while PEG reduced average daily gain compared to lambs without PEG. The reduced performance associated with PEG confirms that the condensed tannins were responsible for some of the production benefits. Lactating dairy cows provided with increasing levels $(0,0.45,0.90$, or $1.80 \%$ or diet DM) of a quebracho (Schinopsis spp.) and chestnut tree (Castanea sativa) tannin extracts decreased intake linearly with tannin intake, with no reductions in milk production, thereby increasing feed efficiency (Aguerre et al., 2016). There are some experiments where condensed tannins have reduced intake and performance though. Barahona et al. (1997) reported 10\% reduction of sheep intake by feeding condensed tannins. Additionally, lambs fed Lotus pedunculatus had low rates of growth (27-125-g/d). Beneficial effects of condensed tannins on performance are context dependent, i.e., source and inclusion level, as well as PSC diversity available in their foodscape.

Plant secondary compounds may also increase dry matter intake and subsequently energy intake, which then increases animal performance. Feeding capsicum (essential oil) increased 
dry matter intake of heifers by $10.7 \%$ (Fandiño et al., 2008). Rodríguez-Prado et al. (2012) also reported an increase in dry mater intake when feeding heifers capsicum, in this case linearly related to the level of capsicum intake with highest increase being $9.8 \%$ with $500-\mathrm{mg} / \mathrm{d}$. Lactating dairy cows consuming cinnemaldehyde and eugenol extract blend increased dry matter intake, with a subsequent $3.6 \%$ increased milk production (Wall et al., 2014). Hence, some of the production benefits associated with PSC occur through increased dry matter and energy intake.

Isoflavonoids, another PSC are often converted to phytoestrogens in the rumen and often affect performance. For example, formononetin in red clover (Trifolium pretense) is metabolized to equol -estrogen- by microorganisms present in the rumen (Kelly et al., 1980), which decreased reproductive efficiency (Kelly et al., 1980; Wocławek-Potocka et al., 2013). While phytoestrogens can be negative in breeding stock, they increase average daily gain in growing animals by increasing growth hormone production (Moorby et al., 2004). These examples with phytoestrogens show how in some instances the same PSC provide benefits or can be detrimental depending on the context.

As mentioned previously, consuming PSC improve animal health through antioxidant defense, or their anthelmintic and antibiotic properties, which in turn will likely increase intake and animal performance. It is common for sick animals to show anorexia and therefore it has been identified as an indicator of discomfort, poor well-being and illness. When analyzing records of 551 Holstein dairy cows and 1,050 lactation records, it was determined that disorders such as mastitis, ketosis, and milk fever, resulted in large reductions in intake $(6.7-14.7 \mathrm{~kg})$ and milk production $(4.1-25.7 \mathrm{~kg})$ on the day of diagnosis (Bareille et al., 2003). All of these disorders have been linked to oxidative stress (Sordillo and Mavangira, 2014) and measurements of oxidative stress, when measured during dry-off (51-60 days before calving), have been used to successfully predict these disorders when the dairy cows transition back into lactation (Wisnieski et al., 2019). Likewise, in growing beef cattle (5,976 animal records) fed in a feedlot, incidence of bovine respiratory disease has been related to lower average daily gain (0.07$\mathrm{kg} / \mathrm{d})$ and hot-carcass weight $(8.16-\mathrm{kg})$ compared to those with no incidence of the disease (Schneider et al., 2009). As with transition dairy cow disorders, bovine respiratory disease incidence has been related to the oxidative stress of finishing cattle (Chirase et al., 2004). Thus, PSC provide antioxidant defense, which may be beneficial in several diseases and disorders in ruminant livestock, thereby reducing their anti-production effects. Moreover, anorexia is a common effect of gastrointestinal parasitic infection, reductions in nutrient use efficiency are key factors behind reduced performance (Parkins and Holmes, 1989), so that the anti-parasitic benefits of some PSC may alleviate these production losses. Based on these relationships, PSC provide health benefits that should then improve animal production.

\section{Food for Thought}

The second listed meta-requirement was improved animal performance, which we argued can be fulfilled, by design through FDD. The conceptual model developed in Figure 2 indicates the kernel theories and relationships behind providing FDD to increase ruminant performance. Taxonomic diversity may increase intake by increasing the hedonic feed value of foods, which is associated with the positive regulation on intake. Increased hedonic feeding value and eudaimonic animal wellbeing are often associated with improved animal performance. Next, PSC coming from a biochemically rich diet alters ruminal fermentation through manipulating rumen microbiome, and altering the site and extent of fermentation. Plant secondary compounds may also improve health and the welfare of ruminants. Collectively, these benefits of taxonomic and PSC diversity can increase energy intake and improve nutrient use efficiency, improving animal performance.

\section{Reducing Environmental Impact}

The livestock industry represents a significant source of environmental pollutants, including greenhouse gas (GHG) emissions and nutrient losses to the waterways. In fact, the global livestock industry accounts for $14.5 \%$ of anthropogenic GHG emissions (Gerber et al., 2013). Enteric methane $\left(\mathrm{CH}_{4}\right)$ and $\mathrm{N}_{2} \mathrm{O}$ emissions from manure are the largest sources of GHG from the livestock industry and represent 39.1 and $16.4 \%$ of total global livestock emissions, respectively (Gerber et al., 2013). Methane is such a large contributor to livestock GHG due to its ability to trap heat, with a 28-times global warming potential (on a 100 year basis) compared to $\mathrm{CO}_{2}$ (IPCC, 2013). As $\mathrm{CH}_{4}$ is a short-lived pollutant (atmospheric half-life of 912 years), other metrics of global warming potential have been proposed, which reduces $\mathrm{CH}_{4}$ warming potential compared with $\mathrm{CO}_{2}$; however, $\mathrm{CH}_{4}$ still represents a significant $\mathrm{GHG}$ no matter the method used for carbon accounting (Thompson and Rowntree, 2020). Enteric $\mathrm{CH}_{4}$ emissions in countries which rely on intensive pastoral systems (particularly dairy) for their ruminant agriculture presents a greater source of GHG. In New Zealand, for instance, enteric $\mathrm{CH}_{4}$ accounts for $34.2 \%$ of total national GHG emissions (Ministry for the Environment, 2019). Additionally, urinary $\mathrm{N}$ excretion adds another significant source of environmental pollution, especially in intensive temperate pastoral operations.

The particular excess of $\mathrm{N}$ supplied by the base dietary forage in these intensive pastoral production systems has then become the "limitation" to increase animal production, welfare and farm profit while reducing environmental impact. Such a limitation relates to the efficiency of nitrogen $(\mathrm{N})$ utilization by ruminants, which rarely exceeds $40 \%$ (Castillo et al., 2001), meaning that at least $60 \%$ of the $\mathrm{N}$ ingested is not utilized to support animal production (e.g., milk, live weight gain), and is excreted, mainly (over 60\%) as urinary nitrogen (UN; Kebreab et al., 2001; Gregorini et al., 2016). In dairy production systems $\sim 82 \%$ of UN is discharged onto pastures (100\% in meat production systems) (Oudshoorn et al., 2008; Clark et al., 2010). Due to the high N load $(1,000 \mathrm{~kg} \mathrm{~N} / \mathrm{ha})$ at the urine patch level, around $20-30 \%$ is leached to the waterways (Selbie et al., 2015) and $0-3.1 \%$ is transformed to $\mathrm{N}_{2} \mathrm{O}$ (a potent GHG), depending on climate and soil type (Cameron et al., 2013). Coupled with recent reports on the associations of nitrates in drinking water and collateral risk of cancer (Schullehner et al., 2018) and the aforementioned 
contributions of $\mathrm{CH}_{4}$ to $\mathrm{GHG}$ emissions, confirm the need to explore feeding strategies to reduce, not only the amount of $\mathrm{N}$ flowing through grazing ruminants, but also the efficiency of rumen fermentation and methane production, in order to respond to the political and public pressures on pastoral farmers. This section will outline how FDD may be used to reduce the environmental impacts of pastoral production systems.

\section{Taxonomic Diversity}

Sustainable intensification is the goal of increasing food production through higher yields (so that more land is not converted for agricultural purposes) through more efficient use of resources (Tedeschi et al., 2015). As discussed above, taxonomic diversity can improve animal performance by increasing feed and energy intake, improving health and well-being, and reducing incidental restriction and augmentation. Increasing animal performance is associated with reducing days required to reach slaughter weight, which means less emission intensity (i.e., reducing GHG per kg of product produced; Capper, 2011). Emission intensity (i.e., g of $\mathrm{CH}_{4}$ /unit of product produced) is an important metric for balancing food production with environmental costs (Waghorn and Hegarty, 2011). Moreover, while increased milk production increases $\mathrm{CO}_{2}$-equivalent emissions per cow from most sources of GHG emissions, the increased production dilutes the total emissions, so that emission intensity has an inverse relationship with total milk production per cow per day (Gerber et al., 2011). McAuliffe et al. (2018) determined a correlation between emission intensity and animal weight gain in pastoral beef production systems as well $(r=-0.77$ to -0.86$)$. From here emerge that FDD may increase animal performance and reduce days to slaughter, thereby reducing total GHG emissions and intensity from pastoral enterprises and providing a pathway for sustainable intensification of grazing ruminant systems.

Functional taxonomic dietary diversity can reduce incidental augmentation and the environmental impacts by improving feed conversion efficiency. Of the total GHG emissions from livestock production, $13 \%$ is from animal feed production (Gerber et al., 2013). Consequently, improving feed conversion efficiency will reduce feed requirements along with the amount of GHG emissions. Increased feed, i.e., nutrient use efficiency, also implies less nutrient excretion as $\mathrm{N}$ in the urine. Additionally, animals that were selected for better feed conversion efficiency (a.k.a. lower residual feed intake) had lower daily methane emissions (g of $\mathrm{CH}_{4} / \mathrm{d}$; Waghorn and Hegarty, 2011). These works would imply that providing functional taxonomic diversity to ruminants, which increases performance levels and nutrient use efficiency, can subsequently reduce the environmental impacts of ruminant production, i.e., sustainable intensification.

\section{Phytochemical Rich Diets and Plant Secondary Compounds}

Plant primary nutrients, such as dietary fats (Beck et al., 2018, 2019) and carbohydrates (Gregorini et al., 2016; Thompson et al., 2019), but also secondary compounds, such as condensed tannins, have been explored for their potential to reduce the environmental impacts of grazing systems (Hristov et al., 2013).
Several classes of PSC, e.g., phenolic compounds, have the ability to alter rumen fermentation patterns and digestion site, reducing methane emissions and urinary $\mathrm{N}$ excretion. Tannins are polyphenolic compounds with strong binding affinity to $\mathrm{N}$, reducing protein degradation in the rumen (Waghorn, 2008). Lambs offered various forage plants with $41 \mathrm{~g} / \mathrm{kg}$ of dry matter additions of a crude tannin extract $(72.5 \%$ condensed tannins) had reduced crude protein digestibility, greater fecal $\mathrm{N}$ excretion, and lower urinary $\mathrm{N}$ excretion (Carulla et al., 2005). Additionally, dairy cows fed increasing proportions of a quebracho tannin extract $(0,0.45,0.90,1.80 \%$ of dietary dry matter $)$, had linearly reduced crude protein digestibility and urinary $\mathrm{N}$ excretion $(\mathrm{g} / \mathrm{d})$, with a linear increase in fecal $\mathrm{N}$ excretion (Aguerre et al., 2016). In many intensively managed pastoral systems, $\mathrm{N}$ is often added in excess of animal requirements-as much as $4 \%$ of diet dry matter in some instances. The majority (60-70\%) of this excess $\mathrm{N}$ is excreted as urinary $\mathrm{N}$, which is a significant environmental pollutant through either gaseous emissions $\left(\mathrm{N}_{2} \mathrm{O}\right.$ or $\left.\mathrm{NH}_{3}\right)$ or leached as nitrate (Di and Cameron, 2007). Nitrogen in feces is more environmentally stable, therefore sward plants are able to uptake that $\mathrm{N}$ as new growth (Waghorn, 2008). Therefore, incremental shifts of $\mathrm{N}$ excretion from urine to feces is viewed as a positive environmental effect.

Tannins also reduce $\mathrm{CH}_{4}$ emissions. Sheep fed 0 or 41 -g of Acacia mearnsii tannin extract had a $13 \%$ reduction in $\mathrm{CH}_{4}$ emissions with $10 \%$ less energy lost to $\mathrm{CH}_{4}$ production (Carulla et al., 2005). Likewise, grazing dairy cows offered two levels of Acacia mearnsii tannins (163 or 244-g of condensed tannins/d) had a 14 and $29 \%$ reduction in methane emissions and a 10 and $22 \%$ reduction in $\mathrm{CH}_{4}$ yield by the low and high addition level, respectively (Grainger et al., 2009). These reductions are due to reduced dry matter digestibility, and a direct inhibition of methanogenic bacteria in the rumen. Tan et al. (2011) reported that increased additions of Leucaena leucocephala tannins ( 0,10 , $15,20,25$, and 30-mg) caused linear reduction in methanogens and protozoa numbers. Jayanegara et al. (2012) conducted a meta-analysis of 30 experiments with a total of 171 treatments and reported that for every additional 1-g tannin/kg dry matter increase there was a $0.11-\mathrm{mL}_{\text {of }} \mathrm{CH}_{4}$ reduction per $\mathrm{g}$ of dry matter intake $\left(R^{2}=0.47\right)$.

Rumen protozoa are one of the main culprits associated with undesirable fermentation traits. For example, they engulf bacteria, decreasing microbial protein flow out of the rumen, produce metabolic $\mathrm{H}^{+}$that is subsequently incorporated in $\mathrm{CH}_{4}$ by methanogens, and increase ruminal $\mathrm{N}$ cycling by increasing deamination of amino acids thereby producing ammonia as an intermediate of metabolism (Leng and Nolan, 1984; Wina et al., 2005). A Yucca schidigera saponins based product (Micro-Aid; DPI Global, Porterville, CA, USA) fed to steers (at either 1.1 or $2.2 \mathrm{~g} / \mathrm{kg}$ of $\mathrm{DM}$ ) reduced protozoal numbers at both levels, and increased flow of microbial $\mathrm{N}$ to the duodenum (McMurphy et al., 2014). Rumen defaunation then emerges as a tool to reduce urinary $\mathrm{N}$ excretion and $\mathrm{CH}_{4}$ emissions (Becker, 1929; Wina et al., 2005). Zhou et al. (2011) reported that saponins derived from tea (Camellia sinensis L.) reduced $\mathrm{CH}_{4}$ emissions $\left(\mathrm{g} \mathrm{CH}_{4} / \mathrm{d}\right)$ in sheep by $10.6 \%$; while Mao et al. (2010) reported a reduction of $27.7 \%$. These reductions were attributed to shifts in 
rumen protozoa populations (Mao et al., 2010; Zhou et al., 2011). Conversely, tea saponins had no effect on $\mathrm{CH}_{4}$ emissions when provided to cattle (Ramírez-Restrepo et al., 2016).

Essential oils of plants contain a variety of phytochemicals, with 20-60 components found in each essential oil (Cobellis et al., 2016). The term "essential" is derived from the word "essence," meaning smell or taste, as these compounds are responsible for providing flavors and odors to certain herbs (i.e., thymol from thyme and oregano; cinnamaldehyde from cinnamon; Calsamiglia et al., 2007). Essential oils have been identified as a potential fermentation modifier for reducing $\mathrm{CH}_{4}$ emissions and $\mathrm{N}$ excretion without compromising digestibility or intake (Cobellis et al., 2016). For example, aucubin (monoterpenoid), found in plantain (Plantago lanceolata; Gardiner et al., 2016; Mangwe et al., 2019) have been reported to reduce urinary $\mathrm{N}$ concentration. Part of aucubin's effect on urinary $\mathrm{N}$ concentration may be explained by a potential effect on rumen protozoa, as essential oils often kill protozoa (Khiaosa-ard and Zebeli, 2013). The aforementioned benefits of essential oils in vivo has been inconsistent (Cobellis et al., 2016), which relates to the variability of essential oils composition as effected by plant species and their adaptive responses to the environment (Calsamiglia et al., 2007).

\section{Food for Thought}

The third meta-requirement of our FDD design is the reduction of environmental impacts associated with pastoral production systems, including enteric methane emissions and urinary $\mathrm{N}$ excretion. This section described the kernel theories presented in Figure 2. Plant secondary compound diversity can reduce environmental impact by altering ruminal fermentation. As outlined above, PSC and taxonomic diversity, i.e., FDD, can also improve animal performance, thereby reducing environmental impact per unit of product, i.e., intensity. By acting through these paths, dietary diversity may reduce the environmental impacts of ruminant production. From these works emerge again that FDD need to be thought and designed in views of phytochemical richness and PSC diversity.

\section{High Quality and Healthy End-Products}

Ruminant end-products for human consumption include meat and milk. Meat and milk quality is related to factors which influence eating experience (e.g., tenderness, juiciness, flavor, etc.), product appearance (e.g., color, smell, etc.), and product stability (e.g., shelf-life). The experiences of the animal, both dietary and mental, can have large implications for the quality of the final products. Furthermore, the post-prandial health impacts of meat and milk may also be related to the animal's previous dietary and mental experiences. Often, the post-prandial effects of food can be seen by the subsequent increase of inflammatory markers (e.g., Li et al., 2010; Nuora et al., 2015), but also have been explored through epidemiological case studies (e.g., Bang et al., 1971). Previous work has highlighted the potential for FDD to improve product quality and human health, i.e., enhance product integrity (Provenza et al., 2019). This section will outline how FDD can improve meat and milk quality and reduce the negative health effects associated with consumption of animal products.

\section{Taxonomic Diversity}

Previously, we provided support that FDD reduces physiological stress in ruminants, as seen by reductions in plasma cortisol (Villalba et al., 2012; Catanese et al., 2013). Both long (i.e., chronic) and short-term (i.e., acute) stress can have drastic impacts on meat and milk product quality. For example, when heifers were provided shade they had a lower neutrophilto-lymphocyte ratio compared to heifers provided no shade, indicating that heifers provided no shade experienced chronic stress. Shaded heifers had a larger proportion graded choice compared with their counterparts (MitlÖhner et al., 2002), indicating a negative effect of chronic stress on meat quality. Preslaughter acute stress is linked with glycogen stores depletion in muscle and thereby raising ultimate $\mathrm{pH}(\geq 6.0)$ at slaughter. The latter reduces water holding capacity, increases firmness, increases sticky texture and dark-red color of the meat (Gardner et al., 2014). As such, reductions in physiological stress by allowing dietary choice of a taxonomically diverse diet may improve end-products quality.

Meat and milk fatty acid (FA) composition largely depends on the animal's diet. Compared with grain fed systems, meat from grass-fed cattle contains greater proportions of omega-3 (n3) FA (Daley et al., 2010). Even under pasture-based diets, botanical composition of the swards influences FA profiles. Mangwe et al. (2020) reported greater milk concentrations of n3 FA for cows grazing plantain (Plantago lanceolata L.) and chicory (Cichorium intybus L.) as compared with perennial ryegrass (Lolium perenne L.), which can be attributed to less ruminal biohydrogenation as a result of faster outflows of digesta from the rumen of cows grazing plantain and chicory. Similar results were previously reported by Muir et al. (2014). This highlights the potential for designing functional increases of dietary taxonomical and biochemical diversity for cows to increase-nutraceutical and prophylactic-FA concentrations in animal end-product (Provenza et al., 2015, 2019).

Saturated FA have been associated with cardiovascular disease in humans (Daley et al., 2010). Red meat contains much higher concentrations of saturated FA than meat from chicken or fish (Ruiz-Núñez et al., 2016). Consequently, dietitians suggest replacing red meat with other sources of meat (Daley et al., 2010). Others contend that saturated FA content of red meat is not a major contributor to cardiovascular disease (Provenza et al., 2019). Moreover the omega 6 (n6) to n3 ratios and n3 FA intake, has also been used to justify "read meat intake reduction" as a health promotor (Ruiz-Núñez et al., 2016). Interest in n3 FA intake began through epidemiological studies, which concluded that Inuit peoples had lower incidence of cardiovascular disease due to greater dietary proportions of fatty fish and seal, high in n3 FA compared with other groups of people (Bang et al., 1971). Other studies have suggested that eating oily fish leads to lower cardiovascular disease ( $\mathrm{Hu}$ et al., 2002). Subsequently, n3 FA supplements have become a common dietary recommendation for humans, despite the little evidence supporting the ability of n3 FA supplements to improve health (Albert et al., 2016; Provenza et al., 2019). In a comprehensive meta-analysis, Aung et al. (2018) reported no health benefits of taking n3 FA supplements. While this meta-analysis has been 
contested by von Schacky (2018), there are often clinical trials which find no benefit to n3 supplements (Sanders et al., 2011; Root et al., 2013). While high in n3, it has been suggested that there are many other compounds contained in fish, which coupled with the FA profile might increase health (Provenza et al., 2019). As such, the bioavailability of n3 FA was greater after participants were given fish rather than pills (Visioli et al., 2003). Therefore, we contend, as do others (Provenza et al., 2015, 2019), that benefits from n3 FA may be observed when consumed in conjunction with synergistic compounds, found in natural sources, which increases the bioavailability of the n3 FA. This also highlights the potential for designing functional increases of dietary taxonomical and biochemical diversity of cows to increase-nutraceutical and prophylactic-FA concentrations in animal end-product (Provenza et al., 2015, 2019).

\section{Phytochemical Rich Diets and Plant Secondary Compound Diversity}

Plant secondary compounds often increase milk and meat quality in terms of antioxidant status (Vasta and Luciano, 2011; Villalba et al., 2019). This increment is largely associated with consumption of phenolic compounds such as flavonoids, isoflavonoids and tannins, but benefits have been shown from other PSC such as terpenoids (Brogna et al., 2014). Ingestion of PSC often increases the antioxidant status of animal products, which in turn increases shelf-life, color stability, and reduces the formation of oxidants and thereby the formation of oxidative products, such as malondialdehyde (Vasta and Luciano, 2011). Ewes fed with distilled rosemary leaf produced lambs with greater meat quality, as seen by delayed lipid oxidation, odor, and spoilage flavor compared with ewes not provided the plant extract (Nieto et al., 2010a, 2011). This was also reported with ewes fed thyme (Thymus zygis ssp.) leaves, whose lambs had improved product quality (by sensory scores) and shelf life (Nieto et al., 2010b). Additionally, lambs fed quebracho (Schinopsis lorentzii) tannins had a $32 \%$ increase in total phenols and a $17 \%$ increase in antioxidant capacity compared to control lambs, improving meat color stability (Luciano et al., 2011). These experiments indicate a direct action of PSC to improve animal antioxidant status and product quality, and subsequently inhibit oxidation product formation.

Direct effects of PSC at the tissue level relate to its absorption and incorporation in tissues (Vasta and Luciano, 2011; Beck and Gregorini, 2020). We further hypothesize that oxidative defense associated with the ingestion of PSC suggests better post-prandial health effects in consumers. Decreasing the formation of oxidant products such as malondialdehyde provide health benefits to humans after ingestion of meat or milk products. Oxidative byproducts have been related to health issues associated with the ingestion of red meat, such as cardiovascular disease and cancer (Bowen and Borthakur, 2004; Chiang and Quek, 2017). Further, products of oxidative damage like malondialdehyde (byproduct of lipid peroxidation) has been linked with post-prandial prandial inflammatory markers. Consumption of malondialdehyde in meat has been associated with increases in post-prandial prandial tumor necrosis factor-2 and monocyte chemotactic protein-1 concentration in the blood (Nuora et al., 2015). Therefore, by providing designed FDD, which improves the antioxidant status of the animals and their products, we can produce high quality and healthier products.

\section{Food for Thought}

The fourth meta-requirement of our design is the improvement of end-product quality to reduce the negative perceptions of adverse health effects associated with the consumption of red meat and dairy products (Figure 1). Physiological stress (both chronic and acute) can reduce meat quality. As taxonomic diversity can improve animal well-being, there may be subsequent improvements to meat quality. Moreover, providing choice of grasses and alternative forages may increase concentration and diversity of n3 FA associated with health benefits. Plant secondary compounds add to quality of animal product by reducing negative post-prandial ingestive health effects. Increased antioxidant status of meat, prolongs shelf-life and inhibits the formation of oxidative by-products associated with storage and cooking, as well as post-prandial prandial inflammation, which hinders human health. As dietary diversity may increase the concentrations of beneficial FA diversity and reduce the production of products associated with negative post-prandial prandial health effects, there is a strong possibility for designed FDD to produce a product with integrity. Product integrity has been defined as "ensuring that food which is offered for sale or sold is not only safe and of the nature, substance and quality expected by the purchaser but also captures other aspects of food production, such as the way it has been sourced, procured and distributed and being honest about those elements to consumers" (Elliott, 2014). We further elaborate the definition of product integrity to include not only product safety and quality as outlined in the previous definition, but also to include moral principles of food production, such as environmental and animal welfare aspects.

\section{Designing Animals to Future Food and Landscapes}

Finally, yet importantly, one consideration to discuss is animals' experience of designed (non-natural) food and landscapes, and how preferences and animal emotions can be "manipulated" in early-life to the particular meta-requirement/s. As such this is our fifth kernel theory (Figure 2). As an example, if an animal is introduced to a new area with unfamiliar feed, they may experience neophobia (i.e., fear of something new; Launchbaugh et al., 1997). This means that animals may not consume plants containing beneficial PSC, put in place purposely, just because they are not familiar with them. In turn, over grazing plants they are familiar with, thereby degrading the landscape, and underutilizing the manmade foodscape may occur. However, livestock can learn to overcome their neophobia, which can be done through early-life exposure, taught by their dam or peers, or influenced by management (Figure 3). This section outlines how grazing ruminants can be taught and/or learn to ingest beneficial plants and formulate a more functional diet, and obtain benefits described in previous sections. Moreover, the question arise can we design an animal's future emotions and personalities for our particular benefits? 


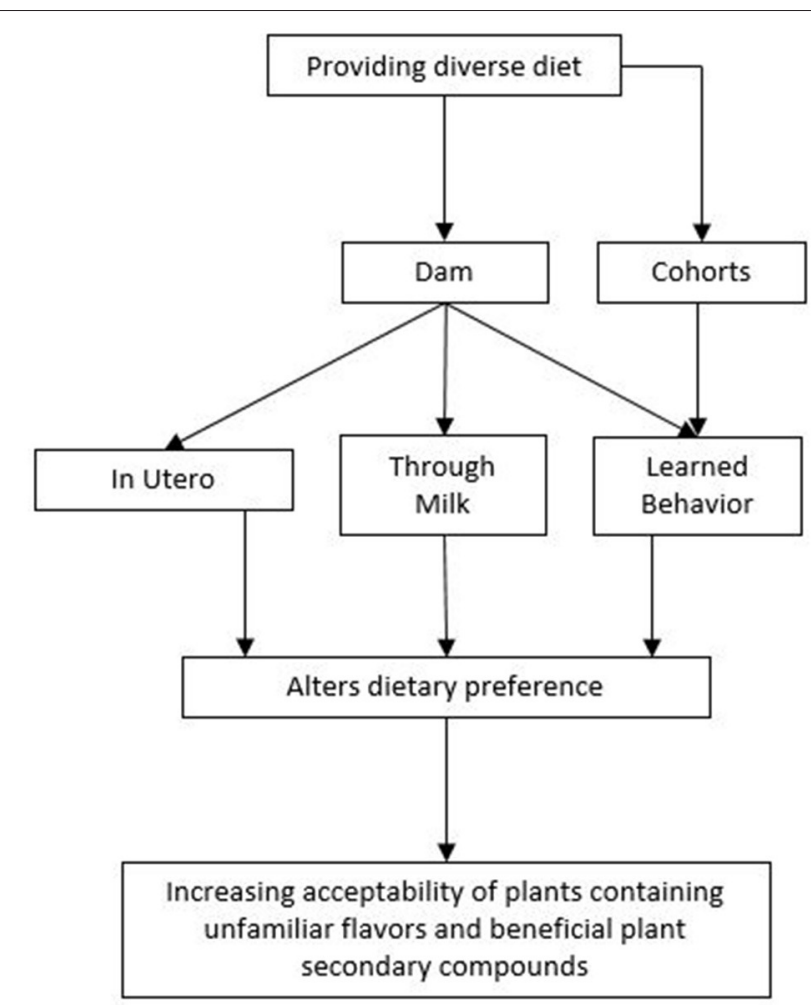

FIGURE 3 | How dietary diversity can program and teach ruminants to alter their dietary preference and increase intake of plants containing beneficial plant secondary compounds.

\section{Learning From Exposure}

Ruminants experience considerable amounts of neophobia when introduced to novel feedstuffs or flavors, i.e., foodscapes (Launchbaugh et al., 1997). Fear of unfamiliar feeds result from evolutionary processes by which foraging ruminants learn to consume beneficial foods, and to avoid nutritionally poor and harmful foods (Provenza and Balph, 1987). Learning to associate post-ingestive responses to a particular feed and flavor has been discussed extensively in the literature (Provenza, 1996; Ginane et al., 2015; Gregorini et al., 2017). This learning shapes current and future dietary preferences and aversions (Provenza and Balph, 1987). Several studies with lambs have highlighted how previous experiences with specific flavors can influence acceptability of novel feeds. Sheep that had previous experience with low quality forages have a greater preference for low quality roughage compared with lambs with no previous experience and previous experiences likewise improved digestibility of the low quality forage (Distel et al., 1994). Launchbaugh et al. (1997) reported that neophobia is reduced when animals are provided a novel feed which was flavored with a familiar flavor. Additionally, repeated exposure to novel feeds increases lamb's acceptance of additional novel feeds (Launchbaugh et al., 1997; Catanese et al., 2012; Villalba et al., 2012). Finally, lambs can learn to associate post-prandial ingestive feedbacks to their diet. For example, gastro-intestinal parasitized lambs have been shown to increase intake of condensed tannins when they have been conditioned to associate them with their anti-parasitic effects (i.e., self-medicate; Villalba and Provenza, 2007; Lisonbee et al., 2009; Villalba et al., 2010, 2014). Further, lambs have been shown to increase intake of specific flavors, if they have been paired with positive postprandial ingestive feedback (Ralphs et al., 1995; Villalba and Provenza, 1996; Villalba et al., 1999; Favreau et al., 2010) and reduce intake for flavors associated with nausea or toxicities (negative post-prandial ingestive feedback; Favreau et al., 2010). Animals learn to associate positive and negative post-ingestive feedbacks to sensorial characteristics (flavors and smells) and will increase or decrease intake, respectively, based on their previous experiences and what they expect to experience. Therefore, animals will implement pre-ingestive cues derived from postingestive feedback (Favreau et al., 2010) as well as predation and life history (Mangel and Clark, 1986) to decide when, what and where to eat. Therefore, by incorporating the time dimension and ontology in the design of FDD animals can be taught or learn to better utilize and experience designed foodscape.

\section{Learning From Peers}

Ruminants are social animals, who follow social cues when posed with new food and landscapes (Moreno García et al., 2020). For example, when Holstein calves were provided novel feed in a social setting, they consumed more feed than animals fed individually (Costa et al., 2014). Lambs who had prior experience to a novel feed with a ewe, who was not its mother, consumed five times as much feed after weaning as lambs who were provided prior experience to the novel feeds alone (Thorhallsdottir et al., 1990). Additionally, naïve cattle alter their grazing distribution, so that they are similar to experienced cattle and this improved their grazing efficiency compared with naïve cattle without experienced peers (Ksiksi and Laca, 2000). Hence, if a naïve animal is introduced to a novel and designed FDD, neophobia may be reduced by providing timely social interactions with experienced peers. Thereby, if a production system implements specific FDD to design their animals, naïve animals can be introduced to their system and will learn from their experienced peers for their own benefit.

\section{Learning From Mother}

Mammals begin developing food preferences in utero (Davis and Stamps, 2004; Beauchamp and Mennella, 2009) with several studies reporting the importance of in utero experience on later in life preferences. Wiedmeier et al. (2012) determined that by providing pregnant cows a high fiber diet (10-fold greater neutral detergent fiber concentration), their calves had a greater intake of ammoniated wheat straw later in life compared to offspring who were provided a low-fiber diet while gestating. Additionally, pregnant ewes fed a high salt diet had offspring with altered preference and lower kidney renin activity compared with offspring born from ewes fed a low salt diet or a pasture diet (Chadwick et al., 2009a,b). This in utero learning of flavors appears to be influenced by timing - stage of gestation- of flavor exposure. When gestating goats were fed Chromonaela odorata in late gestation, their kids had greater preference for Chromonaela odorata compared to exposure during mid-gestation only (Hai 
et al., 2014). Therefore, by providing gestating dams a designed FDD, their offspring would have greater partial preference and lower neophobia later in their life to that FDD. In utero exposure is believed to be an evolutionary process to assist with finding adequate habitats and therefore promote survival (Davis and Stamps, 2004). Thus, by implementing animal design through FDD, offspring can be programmed to recognize, "formulate" and enjoy the designed FDD with diverse plant species that suit the overarching meta-requirements.

Later in life, novel flavor experiences may be introduced to young livestock through their mothers' milk (Provenza and Balph, 1988; Mennella, 1995; Beauchamp and Mennella, 2009). Consumed volatile compounds are imparted into milk and play a large role in dairy products flavor. For example, polyphenols are greater in milk from goats feed diets of sulla (Sulla coronarium L.) compared with goats fed mixed grass hay (Di Trana et al., 2015). Additionally, Besle et al. (2010) measured aromatic compounds related to ultraviolet-absorption of milk, and determined that diet altered the type and amount of these compounds. When these compounds are ingested by the dam's offspring they may provide experience of that feed to the offspring. Several studies have shown how milk flavors alter dietary preference later in life. For example, calves fed flavored milk replacer had greater intake of their starter ration, when it was provided with the same flavor (Morrill and Dayton, 1978). Similarly lambs fed onion and garlic flavored milk, consumed more onion or garlic flavored feed (Nolte and Provenza, 1991). Hence, flavors in milk ingested by young livestock can influence their dietary preference later in life. Definitely, flavor dimensions-as supported by their correspondent PSC-need to be added in the animal design tool box.

Finally, offspring learn consumption habits and preference through observing their dam. For example, lambs learn to selfmedicate with polyethylene glycol when provided a high tannin diet if they observed their mother self-medicating early in life (Sanga et al., 2011). Learning to consume foods from their mother seems to have a larger impact than learning from animals, which are not their mother. For instance, when lambs were offered novel foods with "mom," they consumed twice as much of that food compared with lambs exposed to the novel food with an unfamiliar non-lactating ewe (Thorhallsdottir et al., 1990). The dam-offspring relationship plays an integral role in young ruminant learning; and therefore, in their ability to survive and thrive in new foodscapes. Influence of dams on young ruminants begins in utero, continues by providing flavor familiarity through their milk, and into early life when they teach the young to develop foraging behaviors for the future. Therefore, ruminants born into designed foodscapes based on FDD, can be expected to incorporate and enjoy these plant species in their diets, thereby obtaining the designed benefits.

\section{Food for Thought}

Dietary exposure begins in utero, continues through flavor experience in their mother's milk, and continues through early life experience and learning from their peers (Figure 3). Learning to formulate and enjoy diverse diets is key for animals to experience the nutraceutical, pharmaceutical, and prophylactic benefits of taxonomic and biochemical diversity. As such, it was included as the fifth and final kernel theory. Not only will altering preference for a designed diverse array of plants provide benefits to the animal, it may also prevent over grazing specific plant species and areas, while reducing incidental augmentation and/or restriction with their subsequent negative impacts on performance and the environment.

\section{CONCLUSIONS}

Ruminants can be designed through the implementation of functional dietary diversity to have less environmental impacts, increase production and nutrient use efficiency, and produce a healthy and high quality product by using grazing management and nutritional knowledge and theories to promote and enhance the animal's life. Through design, we obtain the final product, which we can conduct further research on to insure that we have achieved the "MetaRequirements" (i.e., a "Testable Design Product Hypothesis"; see Figure 1). This review highlights the potential for FDD to design ruminant livestock, while improving hedonic and eudaimonic well-being of us and our livestock. Using the concepts described in this manuscript, ruminant livestock producers can design their own FDD, in a manner that fits within the context and confinements of their production setting. In essence, designed animals through FDD will allow us to raise happy, healthy, and environmentally clean products, improve animal production and therefore producer profitability, thereby reconciling ruminant agriculture with the negative viewpoints of society.

\section{AUTHOR CONTRIBUTIONS}

MB was responsible for writing and conceptual development of the manuscript. PG helped develop conceptual framework, provided support with writing and preparation of the manuscript. All authors contributed to the article and approved the submitted version.

\section{ACKNOWLEDGMENTS}

We acknowledge and express our gratitude to Agrisea Ltd. (Paeroa, New Zealand) and Callaghan Innovations (New Zealand) for their funding to support MB's Ph.D. studies. Paul A. Beck from Oklahoma State University is thanked for his beneficial suggestions on the manuscript draft and the students of the Pastoral Livestock Production Lab of Lincoln University for their support and patience with this article's authors, but especially Konagh Garrett and Cameron Marshall. 


\section{REFERENCES}

Aguerre, M. J., Capozzolo, M. C., Lencioni, P., Cabral, C., and Wattiaux, M. A. (2016). Effect of quebracho-chestnut tannin extracts at 2 dietary crude protein levels on performance, rumen fermentation, and nitrogen partitioning in dairy cows. J. Dairy Sci. 99, 4476-4486. doi: 10.3168/jds.2015-10745

Albert, B. B., Cameron-Smith, D., Garg, M. L., Derraik, J. G. B., Hofman, P. L., and Cutfield, W. S. (2016). Marine oils: complex, confusing, confounded? J. Nutr. Intermed. Metab. 5, 3-10. doi: 10.1016/j.jnim.2016.03.003

Atwood, S. B., Provenza, F. D., Villalba, J. J., and Wiedmeier, R. D. (2006). Intake of lambs offered ad libitum access to one of three iso-caloric and isonitrogenous mixed rations or a choice of all three foods. Livest. Sci. 101, 142-149. doi: 10.1016/j.livprodsci.2005.10.022

Atwood, S. B., Provenza, F. D., Wiedmeier, R. D., and Banner, R. E. (2001), Influence of free-choice vs mixed-ration diets on food intake and performance of fattening calves. J. Anim. Sci. 79, 3034-3040. doi: 10.2527/2001.79123034x

Aung, T., Halsey, J., Kromhout, D., Gerstein, H. C., Marchioli, R., Tavazzi, L., et al. (2018). Associations of omega-3 fatty acid supplement use with cardiovascular disease risks meta-analysis of 10 trials involving 77917 individuals. JAMA Cardiol. 3, 225-234. doi: 10.1001/jamacardio.2017.5205

Balcells, J., Aris, A., Serrano, A., Seradj, A. R., Crespo, J., and Devant, M. (2012). Effects of an extract of plant flavonoids (bioflavex) on rumen fermentation and performance in heifers fed high-concentrate diets. J. Anim. Sci. 90, 4975-4984. doi: 10.2527 /jas.2011-4955

Bang, H. O., Dyerberg, J., and Nielsen, A. B. (1971). Plasma lipid and lipoprotein pattern in Greenlandic west-coast eskimos. Lancet. 1, 1143-1146. doi: 10.1016/S0140-6736(71)91658-8

Barahona, R., Lascano, C. E., Cochran, R., Morrill, J., and Titgemeyer, E. C. (1997). Intake, digestion, and nitrogen utilization by sheep fed tropical legumes with contrasting tannin concentration and astringency. J. Anim. Sci. 75, 1633-1640. doi: $10.2527 / 1997.7561633 x$

Barber, J. C. E. (2009). Programmatic approaches to assessing and improving animal welfare in zoos and aquariums. Zoo Biol. 28, 519-530. doi: $10.1002 /$ zoo. 20260

Bareille, N., Beaudeau, F., Billon, S., Robert, A., and Faverdin, P. (2003). Effects of health disorders on feed intake and milk production in dairy cows. Livest. Prod. Sci. 83, 53-62. doi: 10.1016/S0301-6226(03)00040-X

Barrell, G. K. (2019). An appraisal of methods for measuring welfare of grazing ruminants. Front. Vet. Sci. 6, 1-8. doi: 10.3389/fvets.2019. 00289

Baskerville, R., and Pries-Heje, J. (2010). Explanatory design theory. Bus. Inf. Syst. Eng. 2, 271-282. doi: 10.1007/s12599-010-0118-4

Beauchamp, G. K., and Mennella, J. A. (2009). Early flavor learning and its impact on later feeding behavior. J. Pediatr. Gastroenterol. Nutr. 48, S25-30. doi: 10.1097/MPG.0b013e31819774a5

Becerra-Tomás, N., Babio, N., Martínez-González, M. Á., Corella, D., Estruch, R., Ros, E., et al. (2016). Replacing red meat and processed red meat for white meat, fish, legumes or eggs is associated with lower risk of incidence of metabolic syndrome. Clin. Nutr. 35, 1442-1449. doi: 10.1016/j.clnu.2016.03.017

Beck, M. R., and Gregorini, P. (2020). How dietary diversity enhances hedonic and eudaimonic well-being in grazing ruminants. Front. Vet. Sci. 7, 1-14. doi: $10.3389 /$ fvets.2020.00191

Beck, M. R., Thompson, L. R., White, J. E., Williams, G. D., Place, S. E., and Moffet, C. A. (2018). Whole cottonseed supplementation improves performance and reduces methane emission intensity of grazing beef steers 1. Prof. Anim. Sci. 34, 339-345. doi: 10.15232/pas.2018-01722

Beck, M. R., Thompson, L. R., Williams, G. D., Place, S. E., Gunter, S. A., and Reuter, R. R. (2019). Fat supplements differing in physical form improve performance but divergently influence methane emissions of grazing beef cattle. Anim. Feed Sci. Technol. 254:114210. doi: $10.1016 /$ j.anifeedsci.2019.114210

Becker, E. R. (1929). Methods of rendering the rumen and reticulum of ruminants free from their normal infusorian fauna. Proc. Natl. Acad. Sci. U. S. A. 15, 435-438. doi: 10.1073/pnas.15.5.435

Bergen, W. G., and Bates, D. B. (1984). Ionophores: their effect on production efficiency and mode of action. J. Anim. Sci. 58, 1465-1483. doi: $10.2527 /$ jas $1984.5861465 \mathrm{x}$
Berridge, K. C. (2009). "Liking" and "wanting" food rewards: Brain substrates and roles in eating disorders. Physiol. Behav. 97, 537-550. doi: 10.1016/j.physbeh.2009.02.044

Berridge, K. C., and Kringelbach, M. L. (2008). Affective neuroscience of pleasure: Reward in humans and animals. Psychopharmacology 199, 457-480. doi: 10.1007/s00213-008-1099-6

Besle, J. M., Viala, D., Martin, B., Pradel, P., Meunier, B., Berdagué, J. L., et al. (2010). Ultraviolet-absorbing compounds in milk are related to forage polyphenols. J. Dairy Sci. 93, 2846-2856. doi: 10.3168/jds.2009-2939

Boada, L. D., Henríquez-Hernández, L. A., and Luzardo, O. P. (2016). The impact of red and processed meat consumption on cancer and other health outcomes: epidemiological evidences. Food Chem. Toxicol. 92, 236-244. doi: 10.1016/j.fct.2016.04.008

Boissy, A., and Erhard, H. W. (2014). "How studying interactions between animal emotions, cognition, and personality can contribute to improve farm animal welfare," in Genetics and the Behavior of Domestic Animals. 2nd Edn. eds T. Grandin, M. J. Deesing (Cambridge, Massachsetts: Academic Press), 81-113.

Bowen, P. E., and Borthakur, G. (2004). Postprandial lipid oxidation and cardiovascular disease risk. Curr. Atheroscler. Rep. 6, 477-484. doi: 10.1007/s11883-004-0089-3

Brogna, D. M. R., Tansawat, R., Cornforth, D., Ward, R., Bella, M., Luciano, G., et al. (2014). The quality of meat from sheep treated with tannin- and saponinbased remedies as a natural strategy for parasite control. Meat. Sci. 96, 744-749. doi: 10.1016/j.meatsci.2013.10.019

Calsamiglia, S., Busquet, M., Cardozo, P. W., Castillejos, L., and Ferret, A. (2007). Invited review: essential oils as modifiers of rumen microbial fermentation. $J$. Dairy Sci. 90, 2580-2595. doi: 10.3168/jds.2006-644

Cameron, K. C., Di, H. J., and Moir, J. L. (2013). Nitrogen losses from the soil/plant system: a review. Ann. Appl. Biol. 162, 145-173. doi: 10.1111/aab.12014

Capper, J. L. (2011). The environmental impact of beef production in the United States: 1977 compared with 2007. J. Anim. Sci. 89, 4249-4261. doi: $10.2527 /$ jas.2010-3784

Caroprese, M., Albenzio, M., Marzano, A., Schena, L., Annicchiarico, G., and Sevi, A. (2010). Relationship between cortisol response to stress and behavior, immune profile, and production performance of dairy ewes. J. Dairy Sci. 93, 2395-2403. doi: 10.3168/jds.2009-2604

Caroprese, M., Annicchiarico, G., Schena, L., Muscio, A., Migliore, R., and Sevi, A. (2009). Influence of space allowance and housing conditions on the welfare, immune response and production performance of dairy ewes. J. Dairy Res. 76, 66-73. doi: 10.1017/S0022029908003683

Carulla, J. E., Kreuzer, M., Machmüller, A., and Hess, H. D. (2005). Supplementation of Acacia mearnsii tannins decreases methanogenesis and urinary nitrogen in forage-fed sheep. Aust. J. Agric. Res. 56, 961-970. doi: 10.1071/AR05022

Castillo, A. R., Kebreab, E., Beever, D. E., Barbi, J. H., Sutton, J. D., Kirby, H. C., et al. (2001). The effect of energy supplementation on nitrogen utilization in lactating dairy cows fed grass silage diets. J. Anim. Sci. 79, 240-246. doi: $10.2527 / 2001.791240 \mathrm{x}$

Catanese, F., Distel, R. A., Provenza, F. D., and Villalba, J. J. (2012). Early experience with diverse foods increases intake of nonfamiliar flavors and feeds in sheep. J. Anim. Sci. 90, 2763-2773. doi: 10.2527/jas.2011-4703

Catanese, F., Distel, R. A., and Villalba, J. J. (2014). Effects of supplementing endophyte-infected tall fescue with sainfoin and polyethylene glycol on the physiology and ingestive behavior of sheep. J. Anim. Sci. 92, 744-757. doi: $10.2527 /$ jas.2013-6713

Catanese, F., Obelar, M., Villalba, J. J., and Distel, R. A. (2013). The importance of diet choice on stress-related responses by lambs. Appl. Anim. Behav. Sci. 148, 37-45. doi: 10.1016/j.applanim.2013.07.005

Celi, P. (2011). Biomarkers of oxidative stress in ruminant medicine. Immunopharmacol. Immunotoxicol. 33, 233-240. doi: 10.3109/08923973.2010.514917

Celi, P., and Gabai, G. (2015). Oxidant/antioxidant balance in animal nutrition and health: the role of protein oxidation. Front. Vet. Sci. 2:48. doi: $10.3389 /$ fvets.2015.00048

Chadwick, M. A., Vercoe, P. E., Williams, I. H., and Revell, D. K. (2009a). Dietary exposure of pregnant ewes to salt dictates how their offspring respond to salt. Physiol. Behav. 97, 437-445. doi: 10.1016/j.physbeh.2009.03.017 
Chadwick, M. A., Williams, I. H., Vercoe, P. E., and Revell, D. K. (2009b). Feeding pregnant ewes a high-salt diet or saltbush suppresses their offsprings postnatal renin activity. Animal 3, 972-979. doi: 10.1017/S175173110900425X

Chand, N., and Eyre, P. (1977). Nonsteroidal anti-inflammatory drugs: a review. New applications in hypersensitivity reactions of cattle and horses. Can. J. Comp. Med. 41, 233-240.

Chiang, V. S. C., and Quek, S. Y. (2017). The relationship of red meat with cancer: effects of thermal processing and related physiological mechanisms. Crit. Rev. Food Sci. Nutr. 57, 1153-1173. doi: 10.1080/10408398.2014.967833

Chirase, N. K., Greene, L. W., Purdy, C. W., Loan, R. W., Auvermann, B. W., Parker, D. B., et al. (2004). Effect of transport stress on respiratory disease, serum antioxidant status, and serum concentrations of lipid peroxidation biomarkers in beef cattle. Am. J. Vet. Res. 65, 860-864. doi: $10.2460 /$ ajvr.2004.65.860

Clark, C. E. F., McLeod, K. L. M., Glassey, C. B., Gregorini, P., Costall, D. A., Betteridge, K., et al. (2010). Capturing urine while maintaining pasture intake, milk production, and animal welfare of dairy cows in early and late lactation. J. Dairy Sci. 93, 2280-2286. doi: 10.3168/jds.2009-2907

Cobellis, G., Trabalza-Marinucci, M., and Yu, Z. (2016). Critical evaluation of essential oils as rumen modifiers in ruminant nutrition: a review. Sci. Total Environ. 545-546, 556-568. doi: 10.1016/j.scitotenv.2015.12.103

Costa, J. H. C., Daros, R. R., von Keyserlingk, M. A. G., and Weary, D. M. (2014). Complex social housing reduces food neophobia in dairy calves. J. Dairy Sci. 97, 7804-7810. doi: 10.3168/jds.2014-8392

Daley, C. A., Abbott, A., Doyle, P. S., Nader, G. A., and Larson, S. (2010). A review of fatty acid profiles and antioxidant content in grass-fed and grain-fed beef. Nutr. J. 9, 1-12. doi: 10.1186/1475-2891-9-10

Davis, J. M., and Stamps, J. A. (2004). The effect of natal experience on habitat preferences. Trends Ecol. Evol. 19, 411-416. doi: 10.1016/j.tree.2004. 04.006

Deci, E. L., and Ryan, R. M. (2008). Hedonia, eudaimonia, and well-being: an introduction. J. Happiness Stud. 9, 1-11. doi: 10.1007/s10902-006-9018-1

Di Trana, A., Bonanno, A., Cecchini, S., Giorgio, D., Di Grigoli, A., and Claps, S. (2015). Effects of Sulla forage (Sulla coronarium L.) on the oxidative status and milk polyphenol content in goats. J. Dairy Sci. 98, 37-46. doi: $10.3168 /$ jds.2014-8414

Di, H. J., and Cameron, K. C. (2007). Nitrate leaching losses and pasture yields as affected by different rates of animal urine nitrogen returns and application of a nitrification inhibitor - a lysimeter study. Nutr. Cycl. Agroecosyst. 79, 281-290. doi: 10.1007/s10705-007-9115-5

Distel, R. A., Villalba, J. J., and Laborde, H. E. (1994). Effects of early experience on voluntary intake of low-quality roughage by sheep. J. Anim. Sci. 72, 1191-1195. doi: $10.2527 / 1994.7251191 \mathrm{x}$

Elliott, C. (2014). Elliott Review Into the Integrity and Assurance of Food Supply Networks-Final Report: A National Food Crime Prevention Framework. London, UK: HM Government.

Fandiño, I., Calsamiglia, S., Ferret, A., and Blanch, M. (2008). Anise and capsicum as alternatives to monensin to modify rumen fermentation in beef heifers fed a high concentrate diet. Anim. Feed Sci. Technol. 145, 409-417. doi: 10.1016/j.anifeedsci.2007.04.018

Favreau, A., Baumont, R., Duncan, A. J., and Ginane, C. (2010). Sheep use preingestive cues as indicators of postingestive consequences to improve food learning. J. Anim. Sci. 88, 1535-1544. doi: 10.2527/jas.2009-2455

Flythe, M., and Kagan, I. (2010). Antimicrobial effect of red clover (Trifolium pratense) phenolic extract on the ruminal hyper ammoniaproducing bacterium, clostridium sticklandii. Curr. Microbiol. 61, 125-131. doi: 10.1007/s00284-010-9586-5

Gardiner, C. A., Clough, T. J., Cameron, K. C., Di, H. J., Edwards, G. R., and de Klein, M. C. A. (2016). Potential for forage diet manipulation in New Zealand pasture ecosystems to mitigate ruminant urine derived $\mathrm{N}_{2} \mathrm{O}$ emissions: a review. New Zeal. J. Agric. Res. 59, 301-317. doi: $10.1080 / 00288233.2016 .1190386$

Gardner, G. E., Mcgilchrist, P., and Pethick, D. W. (2014). Ruminant glycogen metabolism. Anim. Prod. Sci. 54, 1575-1583. doi: 10.1071/AN14434

Gerber, P., Vellinga, T., Opio, C., and Steinfeld, H. (2011). Productivity gains and greenhouse gas emissions intensity in dairy systems. Livest. Sci. 139, 100-108. doi: $10.1016 /$ j.livsci.2011.03.012
Gerber, P. J., Steinfeld, H., Henderson, B. M. A., Opio, C., Dijkman, J., Falcucci, A., et al. (2013). Tackling Climate Change Through Livestock: A Global Assessment of Emissions and Mitigation Opportunities. Rome: Food and Agriculture Organization of the United Nations (FAO).

Ginane, C., Bonnet, M., Baumont, R., and Revell, D. K. (2015). Feeding behaviour in ruminants: a consequence of interactions between a reward system and the regulation of metabolic homeostasis. Anim. Prod. Sci. 55:247. doi: 10.1071/AN14481

Grainger, C., Clarke, T., Auldist, M. J., Beauchemin, K. A., McGinn, S. M., Waghorn, G. C., et al. (2009). Potential use of Acacia mearnsii condensed tannins to reduce methane emissions and nitrogen excretion from grazing dairy cows. Can. J. Anim. Sci. 89, 241-251. doi: 10.4141/CJAS08110

Gregor, S., and Jones, D. (2007). The anotomy of a design theory. J. Assoc. Inf. Syst. 8, 312-335. doi: 10.17705/1jais.00129

Gregorini, P., Beukes, P. C., Dalley, D., and Romera, A. J. (2016). Screening for diets that reduce urinary nitrogen excretion and methane emissions while maintaining or increasing production by dairy cows. Sci. Total Environ. 551-552, 32-41. doi: 10.1016/j.scitotenv.2016.01.203

Gregorini, P., Villalba, J. J., Chilibroste, P., and Provenza, F. D. (2017). Grazing management: setting the table, designing the menu and influencing the diner. Anim. Prod. Sci. 57, 1248-1268. doi: 10.1071/AN16637

Gregorini, P., Villalba, J. J., Provenza, F. D., Beukes, P. C., and Forbes, J. M. (2015). Modelling preference and diet selection patterns by grazing ruminants: a development in a mechanistic model of a grazing dairy cow, MINDY. Anim. Prod. Sci. 55:360-375. doi: 10.1071/AN14472

Gygax, L. (2017). Wanting, liking and welfare: the role of affective states in proximate control of behaviour in vertebrates. Ethology 123, 689-704. doi: $10.1111 /$ eth. 12655

Hai, P. V., Schonewille, J. T., Van Tien, D., Everts, H., and Hendriks, W. H. (2014). Improved acceptance of Chromonaela odorata by goat kids after weaning is caused by in utero exposure during late but not early pregnancy. Appl. Anim. Behav. Sci. 159, 50-54. doi: 10.1016/j.applanim.2014.07.004

Harfeld, J. L. (2013). Telos and the ethics of animal farming. J. Agric. Environ. Ethics. 26, 691-709. doi: 10.1007/s10806-012-9422-y

Harwatt, H., Sabat,é, J., Eshel, G., Soret, S., and Ripple, W. (2017). Substituting beans for beef as a contribution toward US climate change targets. Clim. Change 143, 261-270. doi: 10.1007/s10584-017-1969-1

Hristov, A. N., Oh, J., Firkins, J. L., Dijkstra, J., Kebreab, E., Waghorn, G., et al. (2013). SPECIAL TOPICS - Mitigation of methane and nitrous oxide emissions from animal operations : I. A review of enteric methane mitigation options. J. Anim. Sci. 91, 5045-5069. doi: 10.2527/jas.2013-6583

Hu, F. B., Bronner, L., Willett, W. C., Stampfer, M. J., Rexrode, K. M., Albert, C. M., et al. (2002). Fish and omega-3 fatty acid intake and risk of coronary heart disease in women. J. Am. Med. Assoc. 287, 1815-1821. doi: $10.1001 /$ jama.287.14.1815

IPCC (2013). "Climate change 2013: the physical science basis," in Contribution of Working Group I to the Fifth Assessment Report of the Intergovernmental Panel on Climate Change, eds T. F. Stocker, G. K. Plattner, M. Tignor, S. K. Allen, J. Boschung, A. Nauels, et al. (Cambridge, UK: Cambridge University Press).

Janssen, M., Busch, C., Rödiger, M., and Hamm, U. (2016). Motives of consumers following a vegan diet and their attitudes towards animal agriculture. Appetite 105, 643-651. doi: 10.1016/j.appet.2016.06.039

Jayanegara, A., Leiber, F., and Kreuzer, M. (2012). Meta-analysis of the relationship between dietary tannin level and methane formation in ruminants from in vivo and in vitro experiments. J. Anim. Physiol. Anim. Nutr. 96, 365-375. doi: 10.1111/j.1439-0396.2011.01172.x

Kasimanickam, R., Kasimanickam, V., Gold, J., Moore, D., Kastelic, J. P., Pyrdek, D., et al. (2019). Injectable or transdermal flunixin meglumine improves pregnancy rates in embryo transfer recipient beef cows without altering returns to estrus. Theriogenology 140, 8-17. doi: 10.1016/j.theriogenology.2019.08.011

Kasimanickam, R. K., Hall, J. B., Estill, C. T., Kastelic, J. P., Joseph, C., Abdel Aziz, R. L., et al. (2018). Flunixin meglumine improves pregnancy rate in embryo recipient beef cows with an excitable temperament. Theriogenology 107, 70-77. doi: 10.1016/j.theriogenology.2017.10.043

Kebreab, E., France, J., Beever, D. E., and Castillo, A. R. (2001). Nitrogen pollution by dairy cows and its mitigation by dietary manipulation. Nutr. Cycl. Agroecosyst. 60, 275-285. doi: 10.1023/A:1012668109662 
Kelly, R. W., Shackell, G. H., and Allison, A. J. (1980). Reproductive performance of ewes grazing red clover (grasslands pawera) or white clover-grass pasture at mating. New Zeal. J. Exp. Agric. 8, 87-91. doi: 10.1080/03015521.1980.10426240

Khiaosa-ard, R., and Zebeli, Q. (2013). Meta-analysis of the effects of essential oils and their bioactive compounds on rumen fermentation characteristics and feed efficiency in ruminants. J. Anim. Sci. 91, 1819-1830. doi: 10.2527/jas.2012-5691

Klita, P. T., Mathison, G. W., Fenton, T. W., and Hardin, R. T. (1996). Effects of alfalfa root saponins on digestive function in sheep. J. Anim. Sci. 74, 1144-1156. doi: $10.2527 / 1996.7451144 x$

Ksiksi, T., and Laca, E. A. (2000). Can social interactions affect food searching efficiency of cattle? Rangel. J. 22, 235-242. doi: 10.1071/RJ0000235

Launchbaugh, K. L., Provenza, F. D., and Werkmeister, M. J. (1997). Overcoming food neophobia in domestic ruminants through addition of a familiar flavor and repeated exposure to novel foods. Appl. Anim. Behav. Sci. 54, 327-334. doi: 10.1016/S0168-1591(96)01194-X

Lee, M. T., Lin, W. C., Yu, B., and Lee, T. T. (2017). Antioxidant capacity of phytochemicals and their potential effects on oxidative status in animals - A review. Asian Australas. J. Anim. Sci. 30, 299-308. doi: 10.5713/ajas.16.0438

Leng, R. A., and Nolan, J. V. (1984). Symposium: protein nutrition of the lactating dairy cow. J. Dairy Sci. 67, 1072-1089. doi: 10.3168/jds.S0022-0302(84)81409-5

Li, Z., Henning, S. M., Zhang, Y., Zerlin, A., Li, L., Gao, K., et al. (2010). Antioxidant-rich spice added to hamburger meat during cooking results in reduced meat, plasma, and urine malondialdehyde concentrations. Am. J. Clin. Nutr. 91, 1180-1184. doi: 10.3945/ajcn.2009.28526

Lisonbee, L. D., Villalba, J. J., Provenza, F. D., and Hall, J. O. (2009). Tannins and self-medication, implications for sustainable parasite control in herbivores. Behav. Proc. 82, 184-189. doi: 10.1016/j.beproc.2009.06.009

Lobley, G. E., and Milano, G. D. (1997). Regulation of hepatic nitrogen metabolism in ruminants. Proc. Nutr. Soc. 56, 547-563. doi: 10.1079/PNS19970057

Lu, C. D., and Jorgensen, N. A. (1987). Alfalfa saponins affect site and extent of nutrient digestion in ruminants. J. Nutr. 117, 919-927. doi: $10.1093 /$ in $/ 117.5 .919$

Luciano, G., Vasta, V., Monahan, F. J., López-Andrés, P., Biondi, L., Lanza, M., et al. (2011). Antioxidant status, colour stability and myoglobin resistance to oxidation of longissimus dorsi muscle from lambs fed a tannin-containing diet. Food Chem. 124, 1036-1042. doi: 10.1016/j.foodchem.2010.07.070

Lykkesfeldt, J., and Svendsen, O. (2007). Oxidants and antioxidants in disease: oxidative stress in farm animals. Vet. J. 173, 502-511. doi: 10.1016/j.tvjl.2006.06.005

Lyman, T. D., Provenza, F. D., Villalba, J. J., and Wiedmeier, R. D. (2011). Cattle preferences differ when endophyte-infected tall fescue, birdsfoot trefoil, and alfalfa are grazed in different sequences. J. Anim. Sci. 89:1131-7. doi: $10.2527 /$ jas.2009-2741

Mangel, M., and Clark, C. (1986). Towards a unified foraging theory. Ecology 67, 1127-1138. doi: 10.2307/1938669

Mangwe, M. C., Bryant, R. H., Beck, M. R., Beale, N., Bunt, C., and Gregorini, P. (2019). Forage herbs as an alternative to ryegrass-white clover to alter urination patterns in grazing dairy systems. Anim. Feed Sci. Technol. 252, 11-22. doi: 10.1016/j.anifeedsci.2019.04.001

Mangwe, M. C., Bryant, R. H., Beck, M. R., Fleming, A. E., and Gregorini, P. (2020). Grazed chicory, plantain or ryegrass-white clover alters milk yield and fatty acid composition of late-lactating dairy cows. Anim. Prod. Sci. 60, 107-113. doi: 10.1071/AN18537

Mao, H. L., Wang, J. K., Zhou, Y. Y., and Liu, J. X. (2010). Effects of addition of tea saponins and soybean oil on methane production, fermentation and microbial population in the rumen of growing lambs. Livest. Sci. 129, 56-62. doi: 10.1016/j.livsci.2009.12.011

McAuliffe, G. A., Takahashi, T., Orr, R. J., Harris, P., and Lee, M. R. F. (2018). Distributions of emissions intensity for individual beef cattle reared on pasture-based production systems. J. Clean. Prod. 171, 1672-1680. doi: 10.1016/j.jclepro.2017.10.113

McCollum, F. T., and Horn, G. W. (1990). Protein supplementation of grazing livestock : a review. Prof. Anim. Sci. 6, 1-16. doi: 10.15232/S1080-7446(15)32251-8

McMurphy, C. P., Sexten, A. J., Mourer, G. L., Sharman, E. D., Trojan, S. J., Rincker, M. J., et al. (2014). Effects of including saponins (Micro-Aid $($ ) on intake, rumen fermentation and digestibility in steers fed low-quality prairie hay. Anim. Feed Sci. Technol. 190, 47-58. doi: 10.1016/j.anifeedsci.2014.01.007
Mellor, D. J. (2016). Updating animal welfare thinking: Moving beyond the "five freedoms" towards "A lifeworth living." Animals. 6:21. doi: 10.3390/ani6030021

Mennella, J. A. (1995). Mother's milk: a medium for early flavor experiences. J. Hum. Lact. 11, 39-45. doi: 10.1177/089033449501100122

Miller-Cushon, E. K., and DeVries, T. J. (2017). Feed sorting in dairy cattle: causes, consequences, and management. J. Dairy Sci. 100, 4172-4183. doi: $10.3168 /$ jds.2016-11983

Ministry for the Environment (2019). New Zealand Greenhouse Gas Inventory 1990-2017. Wellington, New Zealand: Ministry for the Environment.

MitlÖhner, F. M., Galyean, M. L., and McGlone, J. J. (2002). Shade effects on performance, carcass traits, physiology, and behavior of heat-stressed feedlot heifers. J. Anim. Sci. 80, 2043-2050. doi: 10.2527/2002.8082043x

Montuschi, P., Barnes, P., and Roberts, J. L. II. (2007). Insights into oxidative stress: the isoprostanes. Curr. Med. Chem. 14, 703-717. doi: 10.2174/092986707780059607

Moorby, J. M., Fraser, M. D., Theobald, V. J., Wood, J. D., and Haresign, W. (2004). The effect of red clover formononetin content on live-weight gain, carcass characteristics and muscle equol content of finishing lambs. Anim. Sci. 79, 303-313. doi: 10.1017/S1357729800090160

Moreno García, C. A., Maxwell, T. M. R., Hickford, J., and Gregorini, P. (2020). On the search for grazing personalities: from individual to collective behaviors. Front. Vet. Sci. 7:74. doi: 10.3389/fvets.2020.00074

Morrill, J. L., and Dayton, A. D. (1978). Effect of feed flavor in milk and calf starter on feed consumption and growth. J. Dairy Sci. 61, 229-232. doi: 10.3168/jds.S0022-0302(78)83582-6

Muir, S. K., Ward, G. N., and Jacobs, J. L. (2014). Milk production and composition of mid-lactation cows consuming perennial ryegrass-and chicory-based diets. $J$. Dairy Sci. 97, 1005-1015. doi: 10.3168/jds.2013-7183

Muller, L. D., Schaffer, L. V., Ham, L. C., and Owens, M. J. (1977). Cafeteria style free-choice mineral feeder for lactating dairy cows. J. Dairy Sci. 60, 1574-1582. doi: 10.3168/jds.S0022-0302(77)84073-3

Napolitano, F., Girolami, A., and Braghieri, A. (2010). Consumer liking and willingness to pay for high welfare animal-based products. Trends Food Sci. Technol. 21, 537-543. doi: 10.1016/j.tifs.2010.07.012

Nieto, G., Díaz, P., Bañón, S., and Garrido, M. D. (2010a). Dietary administration of ewe diets with a distillate from rosemary leaves (Rosmarinus officinalis L.): influence on lamb meat quality. Meat Sci. 84, 23-29. doi: 10.1016/j.meatsci.2009.08.001

Nieto, G., Díaz, P., Bañón, S., and Garrido, M. D. (2010b). Effect on lamb meat quality of including thyme (Thymus zygis ssp. gracilis) leaves in ewes' diet. Meat. Sci. 85, 82-88. doi: 10.1016/j.meatsci.2009.12.009

Nieto, G., Estrada, M., Jordán, M. J., Garrido, M. D., and Bañón, S. (2011). Effects in ewe diet of rosemary by-product on lipid oxidation and the eating quality of cooked lamb under retail display conditions. Food Chem. 124, 1423-1429. doi: 10.1016/j.foodchem.2010.07.102

Nocek, J. E., Steele, R. L., and Braund, D. G. (1986). Performance of dairy cows fed forage and grain separately versus a total mixed ration. J. Dairy Sci. 69, 2140-2147. doi: 10.3168/jds.S0022-0302(86)80646-4

Nolte, D. L., and Provenza, F. D. (1991). Short communication: food preferences in lambs after exposure to flavors in milk. Appl. Anim. Behav. Sci. 32, 381-389. doi: 10.1016/S0168-1591(05)80030-9

Nordenfelt, L. (2011). Health and welfare in animals and humans. Acta Biotheor. 59, 139-152. doi: 10.1007/s10441-011-9125-1

Nuora, A., Chiang, V. S. C., Milan, A. M., Tarvainen, M., Pundir, S., Quek, S. Y., et al. (2015). The impact of beef steak thermal processing on lipid oxidation and postprandial inflammation related responses. Food Chem. 184, 57-64. doi: 10.1016/j.foodchem.2015.03.059

Oudshoorn, F. W., Kristensen, T., and Nadimi, E. S. (2008). Dairy cow defecation and urination frequency and spatial distribution in relation to time-limited grazing. Livest. Sci. 113, 62-73. doi: 10.1016/j.livsci.2007.02.021

Owen, M. A., Swaisgood, R. R., Czekala, N. M., and Lindburg, D. G. (2005). Enclosure choice and well-being in Giant Pandas: is it all about control? Zoo. Biol. 24, 475-481. doi: 10.1002/zoo.20064

Panzera, M. (2013). Sickness and abnormal behaviors as indicators of animal suffering. Beyond Anthr. 1, 23-31. doi: 10.7358/rela-2013-001-panz

Parkins, J. J., and Holmes, P. H. (1989). Effects of gastrointestinal helminth parasites on ruminant nutrition. Nutr. Res. Rev. 2, 227-246. doi: $10.1079 /$ NRR19890016 
Provenza, F. D. (1995). Postingestive feedback as an elementary deteriminant of food preference and intake in ruminants. J. Range Manag. 48, 2-17. doi: $10.2307 / 4002498$

Provenza, F. D. (1996). Acquired aversions as the basis for varied diets of ruminants foraging on rangelands. J. Anim. Sci. 74, 2010-2020. doi: $10.2527 / 1996.7482010 x$

Provenza, F. D. (2018). Nourishment: What Animals Can Teach Us About Rediscovering Our Nutritional Wisdom. White River Junction, VT: Chelsea Green Publishing.

Provenza, F. D., and Balph, D. F. (1987). Diet learning by domestic ruminants: theory, evidence and practical implications. Appl. Anim. Behav. Sci. 18, 211-232. doi: 10.1016/0168-1591(87)90218-8

Provenza, F. D., and Balph, D. F. (1988). Development of dietary choice in livestock on rangelands and its implications for management. J. Anim. Sci. 66, 2356-2368. doi: 10.2527/jas1988.6692356x

Provenza, F. D., Kronberg, S. L., and Gregorini, P. (2019). Is grassfed meat and dairy better for human and environmental health? Front. Nutr. 6, 1-13. doi: 10.3389/fnut.2019.00026

Provenza, F. D., Meuret, M., and Gregorini, P. (2015). Our landscapes, our livestock, ourselves: restoring broken linkages among plants, herbivores, and humans with diets that nourish and satiate. Appetite 95, 500-519. doi: 10.1016/j.appet.2015.08.004

Provenza, F. D., Villalba, J. J., Dziba, L. E., Atwood, S. B., and Banner, R. E. (2003). Linking herbivore experience, varied diets, and plant biochemical diversity. Small Rumin. Res. 49, 257-274. doi: 10.1016/S0921-4488(03)00143-3

Provenza, F. D., Villalba, J. J., Haskell, J., MacAdam, J. W., Griggs, T. C., and Wiedmeier, R. D. (2007). The value to herbivores of plant physical and chemical diversity in time and space. Crop Sci. 47, 382-398. doi: 10.2135/cropsci2006.02.0083

Ralphs, M. H., Provenza, F. D., Wiedmeier, R. D., and Bunderson, F. B. (1995). Effects of energy source and food flavor on conditioned preferences in sheep. J. Anim. Sci. 73, 1651-1657. doi: 10.2527/1995.7361651x

Ramírez-Restrepo, C. A., Tan, C., O’Neill, C. J., López-Villalobos, N., Padmanabha, J., Wang, J., et al. (2016). Methane production, fermentation characteristics, and microbial profiles in the rumen of tropical cattle fed tea seed saponin supplementation. Anim. Feed Sci. Technol. 216, 58-67. doi: 10.1016/j.anifeedsci.2016.03.005

Rodríguez-Prado, M., Ferret, A., Zwieten, J., Gonzalez, L., Bravo, D., and Calsamiglia, S. (2012). Effects of dietary addition of capsicum extract on intake, water consumption, and rumen fermentation of fattening heifers fed a high-concentrate diet. J. Anim. Sci. 90, 1879-1884. doi: 10.2527/jas.2010-3191

Root, M., Collier, S. R., Zwetsloot, K. A., West, K. L., and McGinn, M. C. (2013). A randomized trial of fish oil omega- 3 fatty acids on arterial health, inflammation, and metabolic syndrome in a young healthy population. Nutr. J. 12, 1-6. doi: 10.1186/1475-2891-12-40

Ruiz-Núñez, B., Dijck-Brouwer, D. A. J., and Muskiet, F. A. J. (2016). The relation of saturated fatty acids with low-grade inflammation and cardiovascular disease. J. Nutr. Biochem. 36, 1-20. doi: 10.1016/j.jnutbio.2015.12.007

Sanders, T. A. B., Hall, W. L., Maniou, Z., Lewis, F., Seed, P. T., and Chowienczyk, P. J. (2011). Effect of low doses of long-chain n-3 PUFAs on endothelial function and arterial stiffness: a randomized controlled trial. Am. J. Clin. Nutr. 94, 973-980. doi: 10.3945/ajcn.111.018036

Sanga, U., Provenza, F. D., and Villalba, J. J. (2011). Transmission of selfmedicative behaviour from mother to offspring in sheep. Anim. Behav. 82, 219-227. doi: 10.1016/j.anbehav.2011.04.016

Schingoethe, D. J. (2017). A 100-year Review: Total mixed ration feeding of dairy cows. J. Dairy. Sci. 100, 10143-10150. doi: 10.3168/jds.2017-12967

Schneider, M. J., Tait, R. G., Busby, W. D., and Reecy, J. M. (2009). An evaluation of bovine respiratory disease complex in feedlot cattle: impact on performance and carcass traits using treatment records and lung lesion scores. J. Anim. Sci. 87, 1821-1827. doi: 10.2527/jas.2008-1283

Schullehner, J., Hansen, B., Thygesen, M., Pedersen, C. B., and Sigsgaard, T. (2018). Nitrate in drinking water and colorectal cancer risk: a nationwide populationbased cohort study. Int. J. Cancer. 143, 73-79. doi: 10.1002/ijc.31306

Selbie, D. R., Lanigan, G. J., Laughlin, R. J., Di, H. J., Moir, J. L., Cameron, K. C., et al. (2015). Confirmation of co-denitrification in grazed grassland. Sci. Rep. 5, 1-9. doi: 10.1038/srep 17361
Seradj, A. R., Abecia, L., Crespo, J., Villalba, D., Fondevila, M., and Balcells, J. (2014). The effect of Bioflavex@and its pure flavonoid components on in vitro fermentation parameters and methane production in rumen fluid from steers given high concentrate diets. Anim. Feed Sci. Technol. 197, 85-91. doi: 10.1016/j.anifeedsci.2014.08.013

Seradj, A. R., Gimeno, A., Fondevila, M., Crespo, J., Armengol, R., and Balcells, J. (2016). Effects of the citrus flavonoid extract Bioflavex or its pure components on rumen fermentation of intensively reared beef steers. Anim. Prod. Sci. 553-560. doi: 10.1071/AN15146

Sgorlon, S., Colitti, M., Asquini, E., Ferrarini, A., Pallavicini, A., and Stefanon, B. (2012). Administration of botanicals with the diet regulates gene expression in peripheral blood cells of Sarda sheep during ACTH challenge. Domest. Anim. Endocrinol. 43, 213-226. doi: 10.1016/j.domaniend.2012.03.001

Sordillo, L. M., and Mavangira, V. (2014). The nexus between nutrient metabolism, oxidative stress and inflammation in transition cows. Anim. Prod. Sci. 54, 1204-1214. doi: 10.1071/AN14503

Spahr, S. L. (1977). Optimum rations for group feeding. J. Dairy Sci. 60, 1337-1344. doi: 10.3168/jds.S0022-0302(77)84031-9

Springmann, M., Clark, M., Mason-D’Croz, D., Wiebe, K., Bodirsky, B. L., Lassaletta, L., et al. (2018). Options for keeping the food system within environmental limits. Nature 562, 519-525. doi: 10.1038/s41586-018-0594-0

Tan, H. Y., Sieo, C. C., Abdullah, N., Liang, J. B., Huang, X. D., and Ho, Y. W. (2011). Effects of condensed tannins from Leucaena on methane production, rumen fermentation and populations of methanogens and protozoa in vitro. Anim. Feed Sci. Technol. 169, 185-193. doi: 10.1016/j.anifeedsci.2011.07.004

Tedeschi, L. O., Muir, J. P., Riley, D. G., and Fox, D. G. (2015). The role of ruminant animals in sustainable livestock intensification programs. Int. J. Sustain. Dev. World Ecol. 22, 452-465. doi: 10.1080/13504509.2015.1075441

Thompson, L. R., Beck, M. R., Gunter, S. A., Williams, G. D., Place, S. E., and Reuter, R. R. (2019). An energy and monensin supplement reduces methane emission intensity of stocker cattle grazing winter wheat. Appl. Anim. Sci. 35, 433-440. doi: 10.15232/aas.2018-01841

Thompson, L. R., and Rowntree, J. E. (2020). INVITED REVIEW: Methane sources, quantification, and mitigation in grazing beef systems. Appl. Anim. Sci. 36, 556-573. doi: 10.15232/aas.2019-01951

Thorhallsdottir, A. G., Provenza, F. D., and Balph, D. F. (1990). Ability of lambs to learn about novel foods while observing or participating with social models. Appl. Anim. Behav. Sci. 25, 25-33. doi: 10.1016/0168-1591(90)90066-M

Ultee, A., Bennik, M. H. J., and Moezelaar, R. (2002). The phenolic hydroxyl group of carvacrol is essential for action against the foodborne pathogen Bacillus cereus. Appl. Environ. Microbiol. 68, 1561-1568. doi: 10.1128/AEM.68.4.1561-1568.2002

van Mosel, M., van't Klooster, A. T., and Malestein, A. (1990). Effects of an inadequate dietary intake of magnesium on osteogenesis in dairy cows during the dry period. Res. Vet. Sci. 48, 280-287. doi: 10.1016/S0034-5288(18)31014-2

Vasta, V., and Luciano, G. (2011). The effects of dietary consumption of plants secondary compounds on small ruminants' products quality. Small Rumin. Res. 101, 150-159. doi: 10.1016/j.smallrumres.2011.09.035

Villalba, J. J., Bach, A., and Ipharraguerre, I. R. (2011). Feeding behavior and performance of lambs are influenced by flavor diversity. J. Anim. Sci. 89, 2571-2581. doi: 10.2527/jas.2010-3435

Villalba, J. J., Beauchemin, K. A., Gregorini, P., and MacAdam, J. W. (2019). Pasture chemoscapes and their ecological services. Transl. Anim. Sci. 3, 829-841. doi: 10.1093/tas/txz003

Villalba, J. J., Catanese, F., Provenza, F. D., and Distel, R. A. (2012). Relationships between early experience to dietary diversity, acceptance of novel flavors, and open field behavior in sheep. Physiol. Behav. 105, 181-187. doi: 10.1016/j.physbeh.2011.08.031

Villalba, J. J., Miller, J., Ungar, E. D., Landau, S. Y., and Glendinning, J. (2014). Ruminant self-medication against gastrointestinal nematodes: evidence, mechanism, and origins. Parasite 21:31. doi: 10.1051/parasite/2014032

Villalba, J. J., and Provenza, F. D. (1996). Preference for flavored wheat straw by lambs conditioned with intraruminal administrations of sodium propionate. $J$. Anim. Sci. 2362-2368. doi: 10.2527/1996.74102362x

Villalba, J. J., and Provenza, F. D. (1997). Preference for flavored wheat straw by lambs conditioned with intraruminal infusions of acetate and propionate. $J$. Anim. Sci. 75, 2905-2914. doi: 10.2527/1997.75112905x 
Villalba, J. J., and Provenza, F. D. (2007). Self-medication and homeostatic behaviour in herbivores: learning about the benefits of nature's pharmacy. Animal 1, 1360-1370. doi: 10.1017/S1751731107000134

Villalba, J. J., Provenza, F. D., Catanese, F., and Distel, R. A. (2015). Understanding and manipulating diet choice in grazing animals. Anim. Prod. Sci. 55, 261-271. doi: 10.1071/AN14449

Villalba, J. J., Provenza, F. D., Hall, J. O., and Lisonbee, L. D. (2010). Selection of tannins by sheep in response to gastrointestinal nematode infection. J. Anim. Sci. 88, 2189-2198. doi: 10.2527/jas.2009-2272

Villalba, J. J., Provenza, F. D., and Rogosic, J. (1999). Preference for flavored wheat straw by lambs conditioned with intraruminal infusions of starch administered at different times after straw ingestion. J. Anim. Sci. 77, 3185-3190. doi: 10.2527/1999.77123185x

Visioli, F., Ris,é, P., Barassi, M. C., Marangoni, F., and Galli, C. (2003). Dietary intake of fish vs. formulations leads to higher plasma concentrations of n-3 fatty acids. Lipids 38, 415-418. doi: 10.1007/s11745-003-1077-x

von Schacky, C. (2018). Rebuttal to Aung et al., "associations of omega-3 fatty acid supplement use with cardiovascular disease risks: meta-analysis of 10 trials involving 77917 individuals." Altern. Ther. Health Med. 24, 8-9.

Waghorn, G. (2008). Beneficial and detrimental effects of dietary condensed tannins for sustainable sheep and goat production-progress and challenges. Anim. Feed Sci. Technol. 147, 116-139. doi: 10.1016/j.anifeedsci.2007.09.013

Waghorn, G. C., and Barry, T. N. (1987). "Pasture as a nutrient source," in Livestock Feeding on Pasture, ed A. M. Nicol (Palmerston North: New Zealand Society of Animal Production), 21-38.

Waghorn, G. C., and Hegarty, R. S. (2011). Lowering ruminant methane emissions through improved feed conversion efficiency. Anim. Feed Sci. Technol. 166-167, 291-301. doi: 10.1016/j.anifeedsci.2011.04.019

Waghorn, G. C., and McNabb, W. C. (2003). Consequences of plant phenolic compounds for productivity and health of ruminants. Proc. Nutr. Soc. 62, 383-392. doi: 10.1079/PNS2003245

Wall, E. H., Doane, P. H., Donkin, S. S., and Bravo, D. (2014). The effects of supplementation with a blend of cinnamaldehyde and eugenol on feed intake and milk production of dairy cows. J. Dairy Sci. 97, 5709-5717. doi: $10.3168 /$ jds.2014-7896

Walls, J. G., Widmeyer, G. R., and El Sawy, A. O. (1992). Building an information system design theory for vigilant EIS. Inf. Syst. Researsch. 3, 36-59. doi: 10.1287/isre.3.1.36

Wang, Y., Douglas, G. B., Waghorn, G. C., Barry, T. N., and Foote, A. G. (1996). Effect of condensed tannins upon the performance of lambs grazing Lotus corniculatus and lucerne (Medicago sativa). J. Agric. Sci. 126, 87-98. doi: $10.1017 /$ S0021859600088833
Webster, J. (1994). Animal Welfare: A Cool Eye Towards Eden. Oxford, UK; Blackwell Science.

Webster, J. (2016). Animal welfare: freedoms, dominions and "A life worth living." Animals 6, 2-7. doi: 10.3390/ani6060035

Wells, J. E., Berry, E. D., and Varel, V. H. (2005). Effects of common forage phenolic acids on Escherichia coli O157 : $\mathrm{H} 7$ viability in bovine feces. Appl Environ Microbiol. 71, 7974-7979. doi: 10.1128/AEM.71.12.7974-7979.2005

Wiedmeier, R. W., Villalba, J. J., Summers, A., and Provenza, F. D. (2012). Eating a high fiber diet during pregnancy increases intake and digestibility of a high fiber diet by offspring in cattle. Anim. Feed Sci. Technol. 177, 144-151. doi: 10.1016/j.anifeedsci.2012.08.006

Wina, E., Muetzel, S., and Becker, K. (2005). The impact of saponins or saponincontaining plant materials on ruminant production - a review. J. Agric. Food Chem. 53, 8093-8105. doi: 10.1021/jf048053d

Wisnieski, L., Norby, B., Pierce, S. J., Becker, T., Gandy, J. C., and Sordillo, L. M. (2019). Predictive models for early lactation diseases in transition dairy cattle at dry-off. Prev. Vet. Med. 163, 68-78. doi: 10.1016/j.prevetmed.2018.12.014

Wocławek-Potocka, I., Mannelli, C., Boruszewska, D., Kowalczyk-Zieba, I., Waśniewski, T., and Skarzyński, D. J. (2013). Diverse effects of phytoestrogens on the reproductive performance: cow as a model. Int. J. Endocrinol. 2013:650984. doi: 10.1155/2013/650984

Yeates, J. W., and Main, D. C. J. (2008). Assessment of positive welfare: a review. Vet. J. 175, 293-300. doi: 10.1016/j.tvjl.2007.05.009

Yurtseven, S., and Görgülü, M. (2004). Effects of grain sources and feeding methods, free-choice vs total mixed ration, on milk yield and composition of German Fawn x Hair crossbred goats in mid lactation. J. Anim. Feed Sci. 13, 417-428. doi: 10.22358/jafs/67429/2004

Zhou, Y. Y., Mao, H. L., Jiang, F., Wang, J. K., Liu, J. X., and McSweeney, C. S. (2011). Inhibition of rumen methanogenesis by tea saponins with reference to fermentation pattern and microbial communities in Hu sheep. Anim. Feed Sci. Technol. 166-167, 93-100. doi: 10.1016/j.anifeedsci.2011.04.007

Conflict of Interest: The authors declare that the research was conducted in the absence of any commercial or financial relationships that could be construed as a potential conflict of interest.

Copyright (C) 2021 Beck and Gregorini. This is an open-access article distributed under the terms of the Creative Commons Attribution License (CC BY). The use, distribution or reproduction in other forums is permitted, provided the original author(s) and the copyright owner(s) are credited and that the original publication in this journal is cited, in accordance with accepted academic practice. No use, distribution or reproduction is permitted which does not comply with these terms. 